\title{
Global and regional sea surface temperature trends during Marine Isotope Stage 11
}

\author{
Y. Milker ${ }^{1,2, *}$, R. Rachmayani' ${ }^{2}$, M. F. G. Weinkauf ${ }^{1,2}$, M. Prange ${ }^{2}$, M. Raitzsch ${ }^{3}$, M. Schulz ${ }^{2}$, and M. Kučera ${ }^{1,2}$ \\ ${ }^{1}$ Department of Geosciences, University of Tübingen, Hölderlinstraße 12, 72074 Tübingen, Germany \\ ${ }^{2}$ MARUM - Center for Marine Environmental Sciences and Faculty of Geosciences, University of Bremen, \\ Klagenfurter Straße, 28359 Bremen, Germany \\ ${ }^{3}$ Alfred Wegener Institute for Polar and Marine Research, Am Handelshafen 12, 27570 Bremerhaven, Germany \\ * now at: Center for Earth System Research and Sustainability (CEN), Institute for Geology, University of Hamburg, \\ Bundesstraße 55, 20146 Hamburg, Germany
}

Correspondence to: Y. Milker (yvonne.milker@uni-hamburg.de)

Received: 9 January 2013 - Published in Clim. Past Discuss.: 12 February 2013

Revised: 14 June 2013 - Accepted: 29 August 2013 - Published: 2 October 2013

\begin{abstract}
The Marine Isotope Stage (MIS) 11 (424-374 ka) was characterized by a protracted deglaciation and an unusually long climatic optimum. It remains unclear to what degree the climate development during this interglacial reflects the unusually weak orbital forcing or greenhouse gas trends. Previously, arguments about the duration and timing of the MIS11 climatic optimum and about the pace of the deglacial warming were based on a small number of key records, which appear to show regional differences. In order to obtain a global signal of climate evolution during MIS11, we compiled a database of 78 sea surface temperature (SST) records from 57 sites spanning MIS11, aligned these individually on the basis of benthic $(N=28)$ or planktonic $(N=31)$ stable oxygen isotope curves to a common time frame and subjected 48 of them to an empirical orthogonal function (EOF) analysis. The analysis revealed a high commonality among all records, with the principal SST trend explaining almost $49 \%$ of the variability. This trend indicates that on the global scale, the surface ocean underwent rapid deglacial warming during Termination $\mathrm{V}$, in pace with carbon dioxide rise, followed by a broad SST optimum centered at $\sim 410 \mathrm{kyr}$. The second EOF, which explained $\sim 18 \%$ of the variability, revealed the existence of a different SST trend, characterized by a delayed onset of the temperature optimum during MIS11 at $\sim 398 \mathrm{kyr}$, followed by a prolonged warm period lasting beyond $380 \mathrm{kyr}$. This trend is most consistently manifested in the mid-latitude North Atlantic and Mediterranean Sea and is here attributed to the strength of
\end{abstract}

the Atlantic meridional overturning circulation. A sensitivity analysis indicates that these results are robust to record selection and to age-model uncertainties of up to 3-6 kyr, but more sensitive to SST seasonal attribution and SST uncertainties $>1{ }^{\circ} \mathrm{C}$. In order to validate the CCSM3 (Community Climate System Model, version 3) predictive potential, the annual and seasonal SST anomalies recorded in a total of 74 proxy records were compared with runs for three time slices representing orbital configuration extremes during the peak interglacial of MIS11. The modeled SST anomalies are characterized by a significantly lower variance compared to the reconstructions. Nevertheless, significant correlations between proxy and model data are found in comparisons on the seasonal basis, indicating that the model captures part of the long-term variability induced by astronomical forcing, which appears to have left a detectable signature in SST trends.

\section{Introduction}

Marine Isotope Stage (MIS) 11 (424-374 ka) (Lisiecki and Raymo, 2005) stands out among the middle Pleistocene interglacials by its unusually long climatic optimum and a subdued orbital forcing due to low orbital eccentricity (Tzedakis et al., 2009). The amplitude of orbital parameters during MIS11 is similar to the Holocene, and MIS11 has been often considered an analogue to the present interglaciation (Berger and Loutre, 1991; Loutre and Berger, 2003; EPICA 
community members, 2004). However, whereas the present interglaciation has so far lasted through one single summer insolation maximum at $65^{\circ} \mathrm{N}$, the MIS11 interglacial optimum spans two such insolation maxima. Further, the deglaciation culminating in MIS11 climatic optimum (Termination V) was associated with an unusually weak orbital forcing and a different phasing of precession and obliquity, making orbital alignment with the Holocene difficult, and driving a protracted deglacial sea-level rise during Termination $\mathrm{V}$, twice as long as during Termination I (Lisiecki and Raymo, 2005; Rohling et al., 2010; Tzedakis, 2010). In contrast to the differences in orbital parameters, the greenhouse gas concentrations in the atmosphere during MIS11 and the rate of their increase during Termination $\mathrm{V}$ were similar when compared to the preindustrial Holocene (Petit et al., 1999; Siegenthaler et al., 2005).

During MIS11, warm interglacial conditions lasted longer than in any other mid- to late Pleistocene interglacials as for instance reflected by the longer period of higher temperatures over Antarctica (Jouzel et al., 2007) and the peak sea level appearing to have been slightly higher than at present (Raymo and Mitrovica, 2012). The presence of an extended "climatic optimum", lasting around $30 \mathrm{kyr}$, has been documented in sea surface temperature records across the world ocean (McManus et al., 1999; Hodell et al., 2000; Kandiano and Bauch, 2003; De Abreu et al., 2005; Dickson et al., 2009; Stein et al., 2009; Voelker et al., 2010), in temperature proxies from Antarctic ice cores (Petit et al., 1999; Jouzel et al., 2007; Pol et al., 2011) and in terrestrial pollen records (Tzedakis, 2010). Like the Holocene, the MIS11 climatic optimum appears to have been a stable interglacial period (Oppo et al., 1998; McManus et al., 1999), characterized by low-amplitude millennial-scale climate variability (Oppo et al., 1998, 2003; Healey and Thunell, 2004; Pol et al., 2011; Vázquez Riveiros et al., 2013).

On the other hand, temperatures in the northern high latitudes during MIS11 appear lower than in the Holocene (Bauch et al., 2000; Helmke et al., 2003), and their temporal development seems to deviate from the global trend (Kandiano et al., 2012). These differences have been linked to changes in the strength of the Atlantic meridional overturning circulation, underlining the importance of the response of oceanic circulation to global forcing during Termination V and MIS11 (Dickson et al., 2009; Vázquez Riveiros et al., 2013). Until now, the congruence of sea surface temperature (SST) trends during MIS11 has never been assessed objectively, on a global basis and with an explicit consideration of dating uncertainty. Such an analysis is essential to determine the robustness and timing of MIS11 climatic optimum and the relationship between MIS11 SST trends with global forcing.

Here, we present a global compilation of sea surface temperature (SST) records for MIS 11, aligned by oxygen isotope stratigraphy, that cover a large proportion of the global oceans in both hemispheres. The aim of this study is to an-

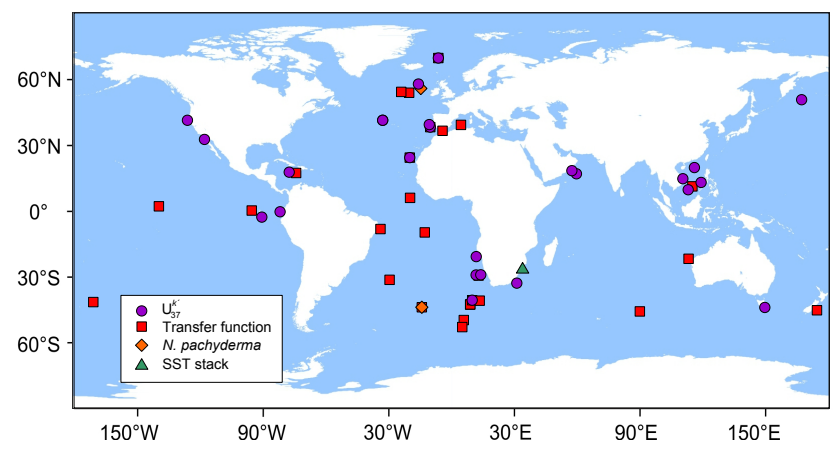

Fig. 1. Position of the sea surface temperature (SST) records used in this study. The compilation contains SST records based on $\mathrm{Mg} / \mathrm{Ca}$, $U_{37}^{k^{\prime}}$, transfer functions (TFs) including an artificial neural network (ANN), scaling of oxygen isotopes values in Neogloboquadrina pachyderma and percentages of $N$. pachyderma (see Sect. 2.1), and one SST stack based on the mean of $\mathrm{Mg} / \mathrm{Ca}, U_{37}^{k^{\prime}}$, and $\mathrm{TEX}_{86}^{H}(\mathrm{Ta}-$ ble 1).

alyze temporal trends in the SST records and to investigate their linkage to global and regional climate variability during this period. Specifically, the following questions will be addressed: (i) what are the roles of orbital and greenhouse gas forcing in MIS11 climate variability, (ii) to what extent is regional climate variability reflected in SST trends, and (iii) how does tempo-spatial climate variability simulated by a state-of-the-art climate model for orbital configuration extremes of MIS11 correspond to that found in proxy records?

\section{Material and methods}

\subsection{Material}

We compiled a total of 78 marine SST records from 57 sites, covering a large geographical range $\left(175^{\circ} \mathrm{E}-172^{\circ} \mathrm{W}\right.$ and $57^{\circ} \mathrm{N}$ to $54^{\circ} \mathrm{S}$ ), and water depths from 826 to $4620 \mathrm{~m}$ (Table 1). Most records stem from cores drilled in the Atlantic and Pacific oceans, but the database also includes records from the Indian Ocean, the Southern Ocean, and the Mediterranean Sea (Fig. 1). We have only chosen SST records for which stable benthic or planktonic foraminiferal oxygen isotope data are available with a sufficient temporal resolution to establish a robust stratigraphic framework for each record (Sect. 2.2). Most data sets were derived from the Pangaea (http://www.pangaea.de) and National Oceanic and Atmospheric Administration (NOAA) (ftp://ftp.ncdc.noaa.gov) websites. Data not available online were provided by the principal investigators or extracted from published figures through digital image processing.

The SST records are based on different proxies. Aware of the significant differences in the part of the seasonal SST cycle that is represented by each proxy, we have attributed the individual SST records to seasons. Thus a total of seven 


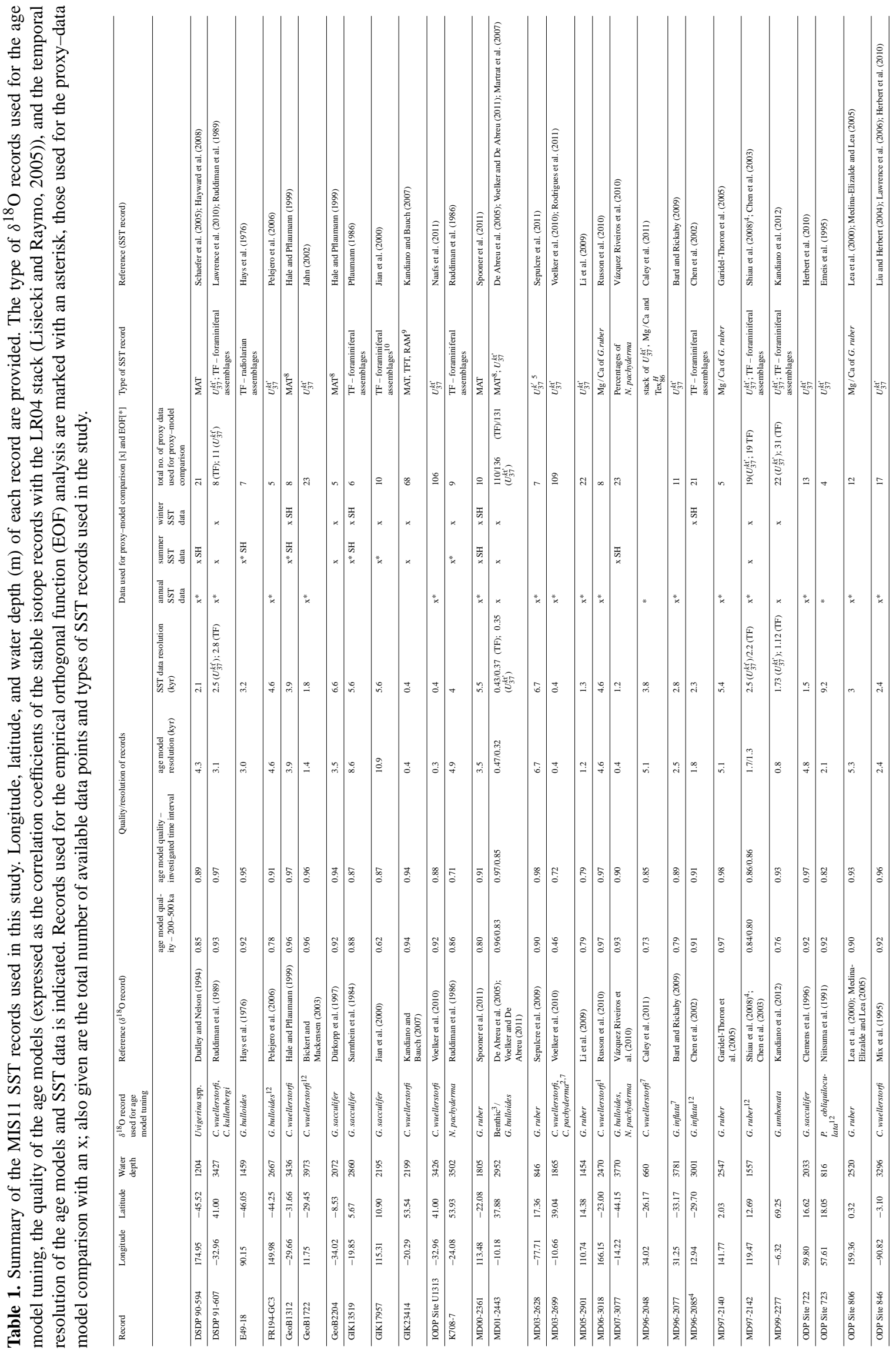




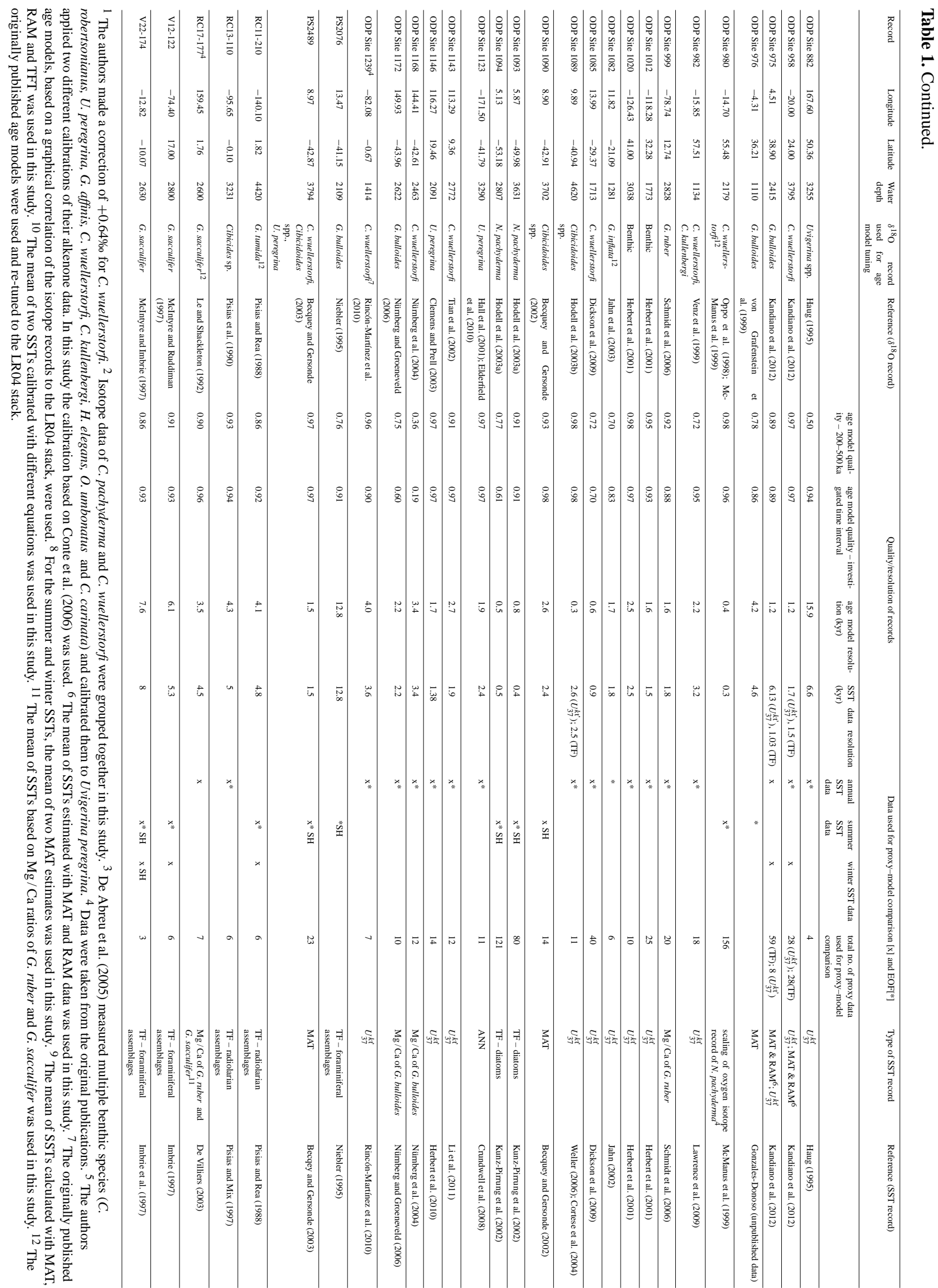


records based on planktonic foraminiferal $\mathrm{Mg} / \mathrm{Ca}$ in low to mid-latitudes were attributed to annual SST (see Barker et al., 2005), and all 25 alkenone $\left(U_{37}^{k^{\prime}}\right)$ records were attributed to annual SST (see Müller et al., 1998) (Fig. 3d). A total of 27 seasonal SST records are based on foraminiferal, radiolarian and diatom assemblages using transfer functions including the modern analog technique (MAT) (Prell, 1985), the Imbrie-Kipp technique (IKT) (Imbrie and Kipp, 1971), the revised analog method (RAM) (Waelbroeck et al., 1998), and SIMMAX (Pflaumann et al., 1996), while one record based on the artificial neural network approach (Malmgren and Nordlund, 1997; Malmgren et al., 2001) was attributed to annual SST (Fig. 3d). Among the individual studies, the calibration data sets and the exact definitions of the seasons vary, but all transfer functions have been calibrated to a representation of "surface" SST, and differences due to different calibration data are unlikely to affect the shape of the SST trends. Finally, one SST record was derived by subtracting the benthic $\delta^{18} \mathrm{O}$ from the $\delta^{18} \mathrm{O}$ signal of the planktonic foraminifer Neogloboquadrina pachyderma (McManus et al., 1999) and another one using the relative abundance of $N$. pachyderma (sinistral) (Vázquez Riveiros et al., 2010). Both of these records are from high-latitude settings and were considered to represent the summer growth season, following the authors of these studies. Furthermore, we included one stack that is based on the mean SSTs calculated from $U_{37}^{k^{\prime}}, \mathrm{Mg} / \mathrm{Ca}$, and $\mathrm{Tex}_{86}^{H}$ measurements (Caley et al., 2011) following the author's statement that the stack gives more accurate SSTs compared to the individual records, and considered that this record represents annual SST. Thus, all SST records can be taken at first approximation to represent a "surface" signature, which has been attributed seasonally as far as possible.

\subsection{Chronostratigraphy}

To allow a direct comparison of SST trends, all records were tuned to the LR04 stack (Lisiecki and Raymo, 2005) on the basis of benthic or planktonic $\delta^{18} \mathrm{O}$. The tuning was carried out for the period between 200 and $550 \mathrm{ka}$ using the AnalySeries software (Paillard et al., 1996) (Fig. 2a-c). The longer tuning time interval enabled a better correlation between the LR04 stack and the $\delta^{18} \mathrm{O}$ data, because it includes more than one glacial-interglacial cycle. For the majority of the records, the $\delta^{18} \mathrm{O}$ data with their corresponding core depths were tuned to the LR04 stack. Where both benthic and planktonic $\delta^{18} \mathrm{O}$ data were available, the benthic records were used for tuning with priority. Depending on the temporal resolution of the records, between 6 and 18 tie points were defined for the target time interval 300-500 ka (Table 1, Fig. S3). This interval was selected because it covers the entire MIS11 and the major portion of the preceding and following glacials, allowing multiple robust tie points to be defined. For record MD03-2699, the tuning to the LR04 stack was problematic, and therefore we used the original age model that is mostly based on the graphical correlation of the
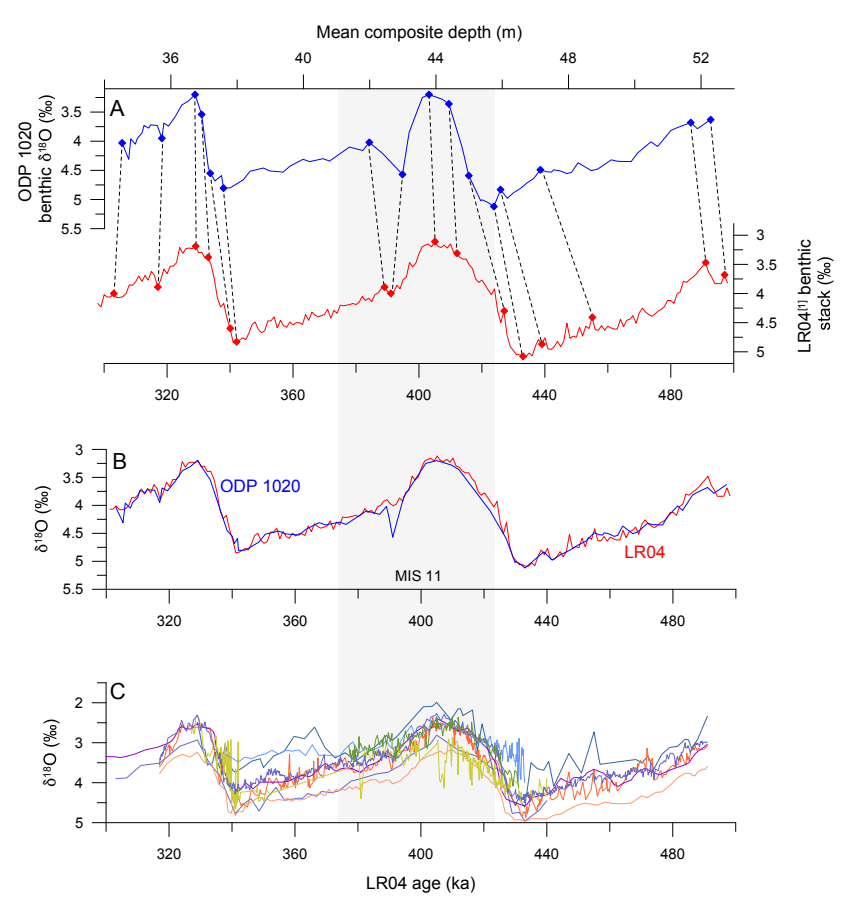

Fig. 2. Example for the age tuning of the benthic $\delta^{18} \mathrm{O}$ record of ODP Site 1020 to the benthic LR 04 stack (Lisiecki and Raymo, 2005): (A) selection of age control points in the $\delta^{18} \mathrm{O}$ of ODP Site 1020 and the LR04 stack, (B) comparison of the tuned $\delta^{18} \mathrm{O}$ record of ODP Site 1020 with the LR04 stack, and (C) nine benthic and planktonic oxygen isotope records from the North Atlantic used in this study tuned to the LR04 stack by the method as shown in panels (A) and (B). The gray area indicates the MIS11 time interval according to Lisiecki and Raymo (2005).

isotope record to ODP Site 980 (given in LR04 ages) (see Voelker et al., 2010, for further explanations). For three sites (MD96-2048, MD 96-2077 and ODP Site 1239), we used the age models in the original publications as they were already based on a graphical correlation of the isotope records to the LR04 stack. For 14 of the compiled records that are included in the LR04 stack, we also have identified a limited number of age control points depending on their resolution such that the number and type of control points was comparable to the other records and then used the age and depth assignment of these points based on the original LR04 age model. The age models of each core are being made available together with all data of the compilation via Pangaea. In addition, age-depth plots for all records used in this study are shown in Fig. S3, highlighting the studied MIS11 interval. The temporal resolution of all proxy records was calculated for the 300-500 ka time interval (Fig. 3a, Table 1), and age model quality was evaluated on the basis of the correlation between the LR04 stack and the stable oxygen isotope curve of each record, as implemented in the AnalySeries software (Table 1). 

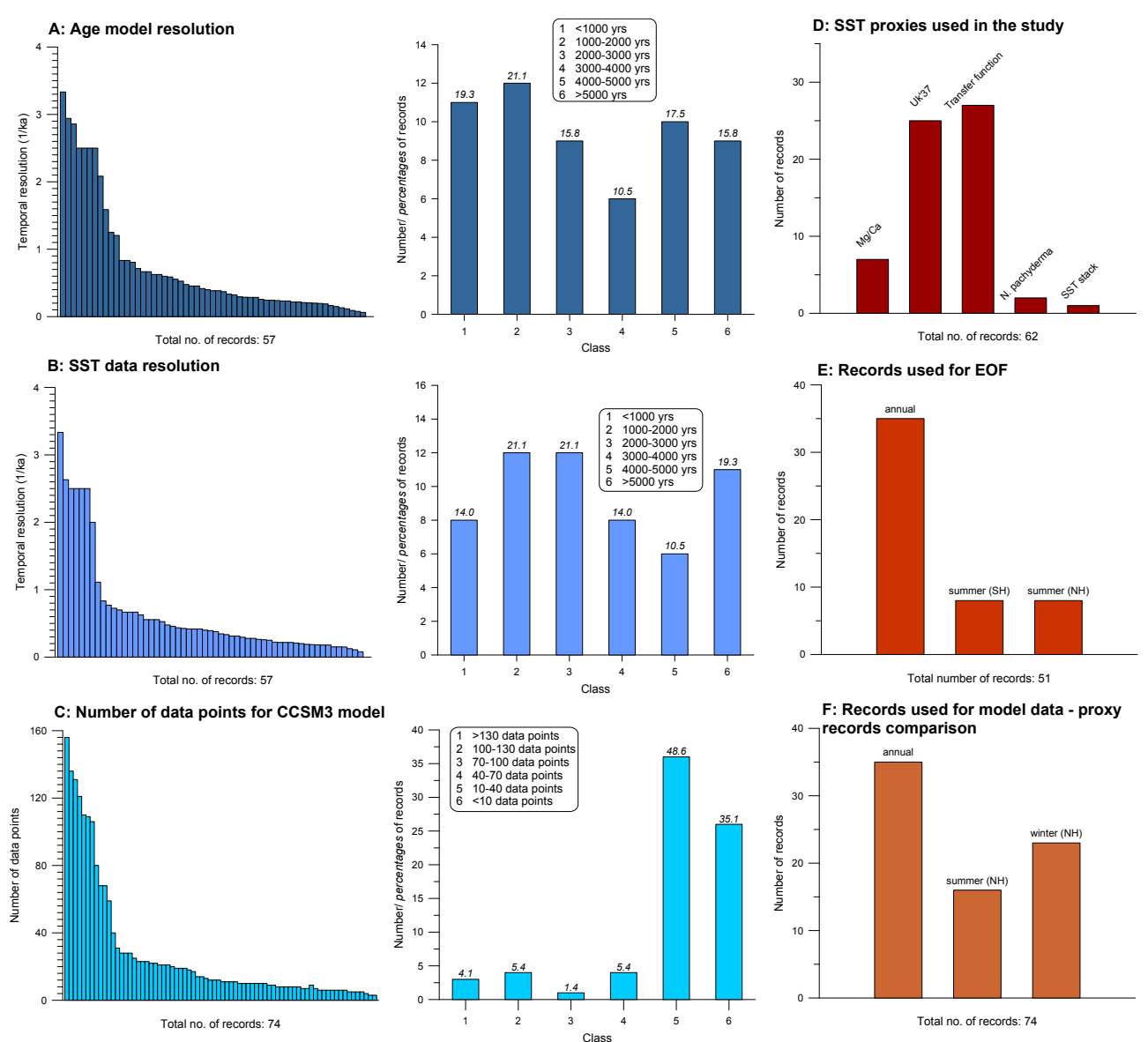

Fig. 3. Mean temporal resolution of the age models based on stable oxygen isotope records used in this study (A). Mean temporal resolution of the SST records used in this study (B). Number of available data points for the comparison of the proxy and model data temperature anomalies for the 390-420 ka time interval and number (C). Number of SST records used in this study for each proxy (D). Seasonal attribution of SST records used for the empirical orthogonal function (EOF) analysis (E) and seasonal attribution of SST records used for the proxy-model data comparison (F).

\subsection{Analysis of SST trends}

To extract principal SST trends in the global compilation, the stratigraphically tuned SST records were subjected to an empirical orthogonal function analysis (principal component analysis applied on equally spaced time series). This method projects a multivariate data set onto a subset of a few principal components, whilst retaining as much information as possible (Hannachi et al., 2007; Jolliffe, 2002; Hammer and Harper, 2006). As the first step of the empirical orthogonal function (EOF) analysis, the tuned SST time series were linearly interpolated to a temporal resolution of $1000 \mathrm{yr}$ allowing a comparison the SST trends reflected by the EOFs with global climate trends across MIS11. All records were normalized to unit variance, preventing the first EOFs from being dominated by variables with large variance. Of the total of 57 sites, SST records from 48 sites (34 representing annual and 14 representing caloric summer SST) covered the interval of 370-430 ka and were included in the analysis (Table 1,
Fig. 3e). This interval was selected to allow the inclusion of the most records, whilst covering the entire MIS11. The 11 records not included in the analysis either ended or started within MIS11. Since we were only interested in the shape of SST trends, we have merged records attributed to annual and summer SST in one joint analysis. We believe this is justified since the biggest difference is likely to be that of a systematic offset, rather than a difference in the shape of the trends. Nevertheless, to assess to what degree this decision may have affected the results, we have also carried out the analyses separately for annual and caloric summer SST.

In order to test the EOF sensitivity to age model uncertainty, the analysis was repeated on data in which the age control points of all records were randomly resampled with an age uncertainty of 3,5, and 6 kyr. The lowest value corresponds to the mean temporal resolution of the records (Table 1), and values higher than $6 \mathrm{kyr}$ were not tested as they would equate to age uncertainties approaching the shortest orbital cycle, implying a total failure of the orbital tuning 
procedure. All age models in this study are based on the age assignment to a small number of distinct features in stable isotope records, between which an interpolation takes place. As a first approximation, we consider that each of the age model control points is liable to the same uncertainty, and that these uncertainties are symmetrical and independent of each other. The randomized age model for each record was then created by stepwise linear correlation between the resampled control points. We have not carried out an autocorrelated age uncertainty propagation between the control points, but the algorithm we used detected and rejected all trials where the resampling created chronological reversals (such a situation may arise when age model control points are closer than twice the age uncertainty of the resampling).

Next, in order to assess the robustness of the EOF pattern to uncertainties in the SST values, the SST reconstructions were resampled under a simulated proxy uncertainty of 1,2 , and $4{ }^{\circ} \mathrm{C}$. The lowest value corresponds to the typical value of an SST proxy uncertainty due to calibration. Higher values of SST uncertainty acknowledge the possibility that the SST reconstructions may be misattributed seasonally between glacial and interglacial ocean conditions, reflecting, for example, shifts in the production season of the proxy carrier. Finally, we used a jackknifing approach to examine the sensitivity of the EOFs to the number of records used in the analysis. EOFs were re-calculated, with 1000 replications, after randomly excluding 5, 15, 25, and 35 records during each replication. The EOF analysis was then carried out with 1000 replicates considering various combinations of age model uncertainty, SST proxy uncertainty and record exclusion. All EOF calculations were carried out with an algorithm written in MATLAB R2012a, which is available in the Supplement (S5).

\subsection{Model-data comparison of climate variability}

A comparison of SST anomalies in the proxy data with climate model output was carried out for three time slices (394, 405 , and 416 ka before present) during the peak MIS11 interglacial when the influence of ice sheets on climate was supposed to be small. The three time slices reflect different extremes of the orbital configurations during peak MIS11. The 394 and 416 ka time slices are characterized by minimum and maximum obliquity (cf. Fig. 8a), respectively, while precession is almost identical. The $405 \mathrm{ka}$ time slice coincides with the LR04 oxygen isotopic minimum (Lisiecki and Raymo, 2005) and high northern summer insolation (cf. Fig. 8a). For model-data comparison, arithmetic averages of all proxy values in each tuned record that fall into a $10 \mathrm{kyr}$ interval centered on the respective model time slice were extracted from the proxy records. In this way, we have made sure that age model uncertainties in the proxy data were taken into account, whilst we acknowledge that the proxy time-slice data are likely to have been smoothed. The time slice simulations were performed with the National Centers for Atmospheric
Table 2. Greenhouse gas concentrations used in forcing the CCSM3 experiments (Siegenthaler et al., 2005; Schilt et al., 2010; Lourergue et al., 2008). See also Fig. 8a.

\begin{tabular}{cccc}
\hline Experiments & $\mathrm{CO}_{2}$ (ppmv) & $\mathrm{CH}_{4}(\mathrm{ppbv})$ & $\mathrm{N}_{2} \mathrm{O}(\mathrm{ppbv})$ \\
\hline $394 \mathrm{ka} \mathrm{BP}$ & 275 & 550 & 275 \\
$405 \mathrm{ka} \mathrm{BP}$ & 280 & 660 & 285 \\
$416 \mathrm{ka} \mathrm{BP}$ & 275 & 620 & 270 \\
\hline
\end{tabular}

Research (NCAR) Community Climate System Model version 3 (CCSM3), which is described in the following section.

CCSM3 is a state-of-the-art coupled climate model that performs without flux corrections. The global model is composed of four separate components representing atmosphere, ocean, land, and sea ice (Collins et al., 2006). Here, we use the low-resolution version of CCSM3, which is described in detail by Yeager et al. (2006). In this version, the resolution of the atmosphere is given by $\mathrm{T} 31\left(3.75^{\circ}\right.$ transform grid) spectral truncation with 26 layers, while the ocean model has a nominal horizontal resolution of $3^{\circ}$ (like the sea-ice component) with 25 vertical levels. The latitudinal resolution of the ocean grid is variable, with finer resolution around the Equator $\left(0.9^{\circ}\right)$. The land model is defined on the same horizontal grid as the atmosphere and includes components for biogeophysics, biogeochemistry, the hydrologic cycle, as well as a dynamic global vegetation model. In order to improve the simulation of vegetation cover, new parameterizations for canopy interception and soil evaporation have been implemented into the land component (Oleson et al., 2008).

A pre-industrial control run was performed following the protocol established by the Paleoclimate Modelling Intercomparison Project, Phase 2 (Braconnot et al., 2007; OttoBliesner et al., 2006; Merkel et al., 2010). The control run was integrated for $600 \mathrm{yr}$ starting from present-day initial conditions. For the selected time slices, appropriate orbital parameters (Berger, 1978) and greenhouse gas concentrations were prescribed, as given in Table 2, while all other forcings (ice sheet configuration, ozone distribution, sulfate aerosols, carbonaceous aerosols, solar constant) were kept at pre-industrial levels. Starting from the last year of the (quasi)equilibrated pre-industrial control run, all simulations were integrated for $400 \mathrm{yr}$ so that the surface climatologies could reach a statistical equilibrium. For each experiment, the mean of the last 100 simulation years was used for analysis.

For a direct proxy-model comparison, we used only such proxy SST records for which at least one value was available in each of the three time-slice intervals and calculated the differences between the SST average for the three time slices and the SST average of each time slice. In all cases, the seasonal attribution has been preserved, allowing data-model comparison on a seasonal basis. The comparison is synoptic in that northern summer SST and southern winter SST are analyzed together and vice versa. The eventually selected 74 
records from a total of 52 sites contain a total of 35 annual, 16 Northern Hemisphere summer, and 23 Northern Hemisphere winter SST records (Fig. 3f, Table 1). Model data have been extracted from the surface layer $(0-20 \mathrm{~m})$ field of the nearest grid cell to each proxy record. For the data-model comparison, we calculated the proxy-based and modeled SST anomalies of the Northern Hemisphere summer (July-September in the model) and winter (January-March in the model) periods and the annual SST anomalies relative to the mean SST of the 390-420 ka time interval (the average of the 394, 405, and $416 \mathrm{ka}$ time slices in the model).

When testing for the correlation between SST anomalies retrieved from proxy data and model calculations on a perseason basis, part of the uncertainty is whether or not the proxy data have been assigned to the correct season. In order to test the validity of our assignments (compare also with Sect. 2.1), we applied two randomization tests on the data set showing the best correlation between proxy and model (in this case $416 \mathrm{ka}$ summer). Using all 52 records in that time slice, we ran 10000 permutations during which we correlated summer anomaly data of the model with random season data of the proxies. In a second randomization we introduced one more degree of freedom by randomly choosing only 30 of the 52 records available and correlating a randomly assigned seasonal data set in the proxy data with the summer values of the model data. To test the agreement between proxy and modeled SST anomalies in a quantitative way, the correlation between the proxy and modeled data for each season and each time slice was calculated using the PAST software package (Hammer et al., 2001). The type of correlation analyses was adapted to the results of normality tests applied on the data sets. Pearson's product-moment correlation $(r)$ was used where the data were normally distributed (ShapiroWilk test), while Spearman's rank-order correlation $(\rho)$ was used when the data did not meet these requirements. In order to assess not only the strength of the direct relationship between the modeled and proxy-based anomalies, but also to compare the direction of change in the data, Cohen's $\kappa$ (Cohen, 1960) was used. Here, the temperature anomaly values were categorized into three nominal values, i.e., negative, positive, and no change relative to the mean SST of the 390-420 ka time interval (the average of the 394, 405, and $416 \mathrm{ka}$ time slices in the model data). On the basis of those categories, it was counted how often proxy data and model predictions were in agreement with each other, and how often they contradicted and, if so, in which way they contradicted (e.g., model is positive and proxy is negative, or model has no change and proxy is positive). This resulted in contingency tables with counts of all nine possible relations, from which Cohen's $\kappa$ and corresponding $p$ values (for $\mathrm{H} 0=$ no agreement between raters) were calculated in the SPSS software package (version 20). Verbal assignments of quality of agreement solely on the basis of the $\kappa$ value are in accordance with standard values given in the literature (e.g., Altman, 1991). In order to quantify the differences in variability in the proxy records and the climate model, the variance of the SST anomalies in the proxy and model data sets was calculated for each time slice and season, and compared using an $F$ test. Finally, we determined whether or not the proxy pattern for each time slice can be considered as significant deviation from no change. To this end, we calculated the confidence interval for the mean proxy-based SST anomaly values using means of error propagation, where the confidence interval is a function of both the number of records averaged and the variance within those records.

\section{Results}

\subsection{Age model quality}

In order to quantify the quality of our age models, we examined both the correlation of the $\delta^{18} \mathrm{O}$ records with the LR04 stack (Lisiecki and Raymo, 2005) as well as their temporal resolution. The majority of the benthic isotope records (44 records, i.e., $77 \%$ ) show a high correlation of $r \geq 0.80$ for the entire tuning time interval between $\sim 200$ and $\sim 550 \mathrm{ka}$ (Table 1). Ten records $(18 \%)$ show a moderate correlation with the LR04 stack $(r=0.60$ between $r=0.80)$. Three records show a low correlation with the benthic stack with $r=0.50$ for ODP Site 882, $r=0.46$ for MD03-2699, and $r=0.36$ for ODP Site 1168. The records from MD03-2699 and ODP Site 1168 are characterized by low $\delta^{18} \mathrm{O}$ values in the later part of MIS11. According to Voelker et al. (2007), the benthic $\delta^{18} \mathrm{O}$ values of core MD03-2699 are strongly affected by the Mediterranean outflow water (MOW) during glacial and interglacial inceptions, making it difficult to establish their benthic-isotope-based age model we have used in our study. The benthic $\delta^{18} \mathrm{O}$ record of ODP Site 1168 was tuned with the help of the original age model given in Nürnberg et al. (2004) as their isotope curve does not show the typical MIS11 pattern. The ODP Site 882 benthic $\delta^{18} \mathrm{O}$ record has the lowest resolution of all records used, and the tuning to the LR04 stack was guided by the age model given in Haug (1995). When only the MIS11 interval (370-430 ka) is considered, 52 records $(91 \%)$ show a correlation with the LR04 stack higher than $r=0.8$. Four records (8\%) exhibit correlation coefficients between $r=0.6$ and $r=0.8$, and one record (ODP Site 1168) has a correlation of less than 0.6 (i.e., $r=0.19$ ) (Table 1 ). To determine the $\delta^{18} \mathrm{O}$ records' quality, the records were divided into classes depending on their temporal resolution. For records MD97-2142 and MD01-2443, the mean temporal resolution based on two different $\delta^{18} \mathrm{O}$ records was calculated (Table 1). Eleven records (19.3\%) have a temporal resolution higher than $1000 \mathrm{yr}$ (Fig. 3a). A total of 21 records $(36.9 \%)$ have a temporal resolution between 1000 and $3000 \mathrm{yr}$, and 16 records $(28.0 \%)$ have a resolution between 3000 and $5000 \mathrm{yr}$. Nine of the records $(15.8 \%)$ have a low temporal resolution of less than $5000 \mathrm{yr}$ (Fig. 3a). The mean temporal resolution of all records used 
is approximately $3000 \mathrm{yr}$. This is the value that was used as the minimum estimate of age uncertainty in the age-model sensitivity simulation.

\subsection{Temporal resolution of SST proxy records}

To evaluate the temporal resolution of SST records, the records have been divided into the same classes as described above for the $\delta^{18} \mathrm{O}$ records. For records having more than one SST record, the mean temporal SST resolution was calculated for this evaluation. A total of eight SST records $(14.0 \%)$ have a temporal resolution of more than $1000 \mathrm{yr}$ (Fig. 3b), 24 records $(43.0 \%$ ) a moderate temporal resolution between 1000 and $3000 \mathrm{yr}$, and 14 records $(24.6 \%)$ a resolution between 3000 and 5000 yr. Eleven SST proxy records $(19.3 \%$ ) have a low resolution of less than $5000 \mathrm{yr}$ (Fig. 3b). The mean temporal resolution is $3127 \mathrm{yr}$, indicating that the records should collectively be able to resolve orbital-scale variability, but not millennial variability.

Depending on the specific temporal resolution of each record, varying amounts of SST data points were available for the comparison of the proxy with modeled SST anomalies for the 390-420 ka time interval. From a total of 74 records used for this comparison, 26 records $(35.1 \%)$ provided only less than ten data points each for the total time interval (Fig. 3c). For 36 records (48.6\%) 10-40 data points per record were available, whereas nine records $(12.1 \%)$ contained more than 40 but less than 130 data points per record, and three records $(4.1 \%)$ provided more than 130 data points each.

\subsection{Empirical orthogonal function analysis}

EOF analysis (Fig. 4) of the 48 SST records spanning the entire target time interval revealed the existence of a strong commonality in the shape of the SST trends. The first three EOFs together explained around three quarters of the variability in the data, irrespective of the combination of agemodel and SST-proxy uncertainty and record selection (Table 3). Almost one half of the variability is explained by the first EOF, which describes a temporal trend of a rapid deglaciation, followed by a broad temperature optimum centered on $410 \mathrm{ka}$ and a slow decrease of SST towards the end of MIS11. The second EOF explains nearly $19 \%$ of the total variability and shows a delayed onset of the temperature optimum during MIS11 after $410 \mathrm{ka}$, followed by a prolonged warm period lasting beyond $380 \mathrm{ka}$. The third EOF explains around $8 \%$ of the total variability and shows a cyclic pattern with a period of about $30 \mathrm{kyr}$.

For the first EOF, $42 \%$ of the records have significant positive loadings $>0.75,31 \%$ of the records positive loadings between 0.5 and 0.75 , and only four records (ODP Site 999, ODP Site 1168, RC11-210 and V22-174) show negative loadings (Fig. 5). The latter records reflect SST changes in the tropical Atlantic and Pacific, as well as in southeast- ern Australian coastal regions. In contrast, the loadings of the second EOF are more diverse and show a geographical pattern. Only three of the records show strong positive loadings $>0.75$ to EOF2 and are primarily associated with SST changes in the mid-latitude North Atlantic region (IODP Site U1313) and the Mediterranean Sea (ODP Site 976) (Fig. 5). Records with positive loadings to EOF2 between 0.5 and 0.75 are further observed in the mid-latitude North Atlantic region (ODP Site 958), in the Caribbean Sea (V12-122), on the western coast of South Africa (ODP Site 1082), northwest of Australia (MD00-2361), and in the North Pacific (ODP Site 882, RC11-210). Finally, high loadings of the third EOF are limited to a few records, indicating that this EOF (and all subsequent EOFs) tends to express patterns specific for individual sites, rather than highlighting commonalities among the records.

Both the shape of the first two EOFs (Fig. 4) and the amount of variance explained by them are remarkably robust to age-model and temperature uncertainty (Table 3). The temperature uncertainty has a stronger influence on the EOF robustness than the uncertainty of the age model. Compared with a temperature uncertainty of $1^{\circ} \mathrm{C}$, a temperature uncertainty of $4{ }^{\circ} \mathrm{C}$ reduces the variance explained by EOF1 from 49.0 to $35.9 \%$ (Table 3). In contrast, an increase of age uncertainty from 3 to $6 \mathrm{kyr}$ reduces the amount of variance explained by the first EOF by less than $1 \%$ (Table 3 ). Similarly, a reduction of the number of records included in the analysis has a relatively small influence on the variance that is explained by the EOFs, as long as the subsampling is limited to more than $50 \%$ of the total number of records (Table 3 ).

In contrast to the robustness of the first two EOFs, the third EOF scores are sensitive both with respect to temperature uncertainty and record selection (jackknifing). The cyclic signal of EOF3 loses significance already at temperature uncertainty of $2{ }^{\circ} \mathrm{C}$ and with jackknifing at the level of withholding around 25 records at a time (Fig. 4). This behavior is consistent with the EOF3 signal being associated with a small number of records characterized by low amplitude of the SST signal. We conclude that the third EOF, and by inference all subsequent ones, does not express any general climatic signals and is not interpreted further in this study.

The EOF analyses carried out separately for the 34 annual and 14 summer SST records show similar general trends for the first two components, but small temporal lags with respect to the joint analysis (Fig. S1). The lags amount to around 3-4 kyr, which coincides with the average temporal resolution of the records. The loadings of individual records in the separate analyses are largely similar to those in the joint analysis (Fig. S2).

\subsection{Comparison of proxy with modeled SST}

The most striking pattern when comparing the proxy-based SST anomalies with model results is the large difference in their variance. Whilst proxy-based SST anomalies range 

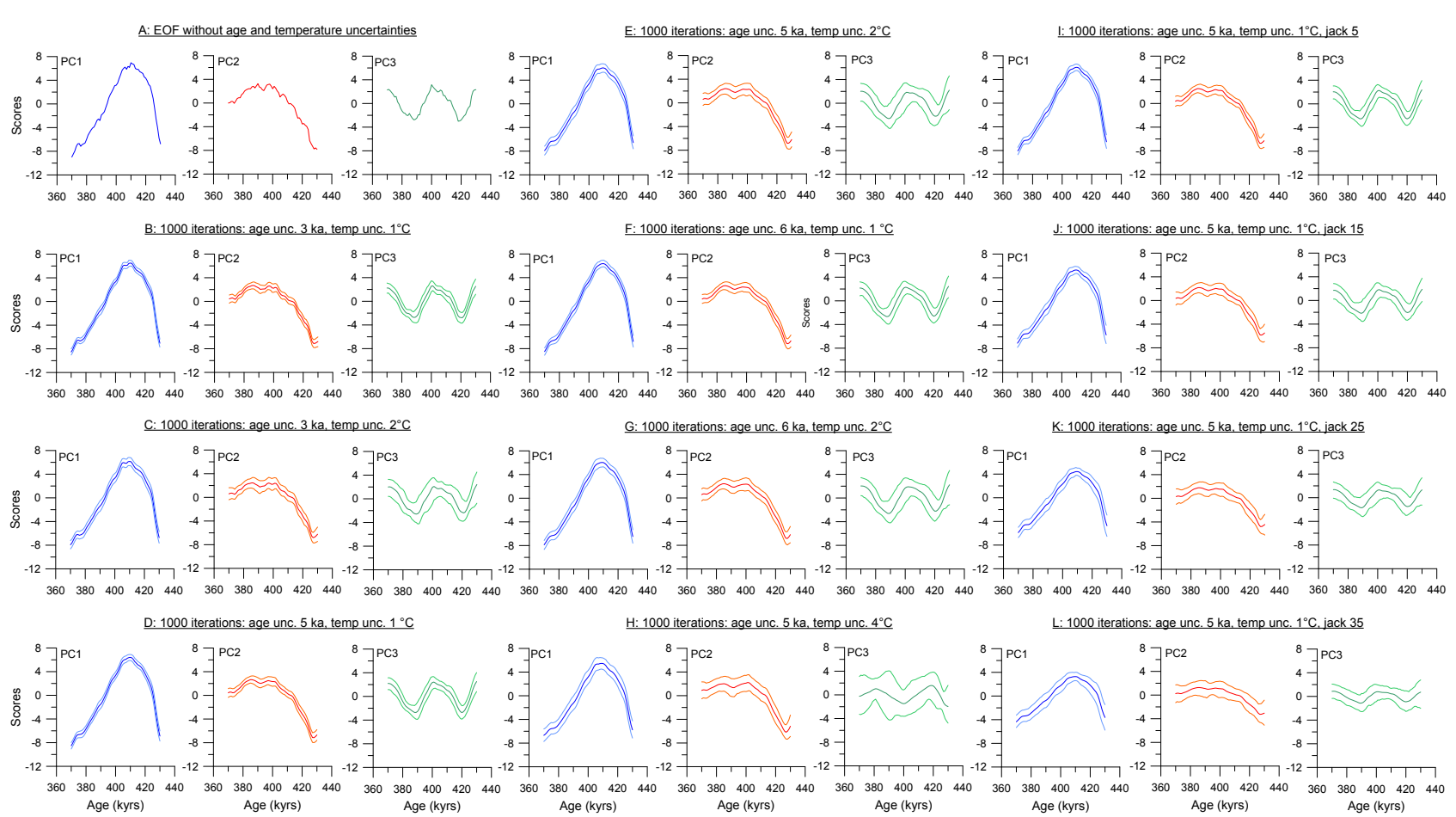

Fig. 4. Results of an empirical orthogonal function (EOF) analysis of MIS11 SST records (Fig. 1, Table 1), including results of a sensitivity analysis with respect to age and temperature uncertainties. Re-calculations were made for age uncertainties of 3,5 and $6 \mathrm{kyr}$, and for temperature uncertainties of 1,2 and $4{ }^{\circ} \mathrm{C}$. To test for sensitivity of the EOF to record selection, jackknifing was applied and $5,15,25$ and 35 samples were randomly excluded from the data set (age and temperature uncertainties were set to $5 \mathrm{kyr}$ and $1^{\circ} \mathrm{C}$ ). All calculations were made with 1000 iterations, and the confidence intervals are given for each analysis. For variances explained by the EOFs, see Table 3 .

Table 3. Variances explained by the first three empirical orthogonal functions (EOFs) of the MIS11 SST records, including 5 and $95 \%$ confidence limits (see also Fig. 4). Re-calculations were made with varying age and temperature uncertainties and a random exclusion of records (jackknifing, jack5 means that five records were excluded per replication). Control run refers to analysis of raw data without consideration of uncertainties. EOF results presented in Fig. 8 and discussed in Sect. 4.1 are given in bold.

\begin{tabular}{lccccccccr}
\hline Parameter & EOF1 & $5 \%$ & $95 \%$ & EOF2 & $5 \%$ & $95 \%$ & EOF3 & $5 \%$ & $95 \%$ \\
\hline control run & 51.43 & & & 19.87 & & & 6.91 & & \\
$1000,3 \mathrm{kyr}, 1^{\circ} \mathrm{C}$ & 49.22 & 47.40 & 51.07 & 18.34 & 16.89 & 19.92 & 7.56 & 6.65 & 8.60 \\
$1000,3 \mathrm{kyr}, 2^{\circ} \mathrm{C}$ & 44.85 & 42.51 & 47.49 & 17.30 & 15.37 & 19.36 & 7.89 & 6.62 & 9.22 \\
$\mathbf{1 0 0 0}, \mathbf{5 ~ k y r}, \mathbf{1}^{\circ} \mathbf{C}$ & $\mathbf{4 9 . 0 0}$ & $\mathbf{4 7 . 0 6}$ & $\mathbf{5 1 . 0 2}$ & $\mathbf{1 8 . 4 4}$ & $\mathbf{1 6 . 6 7}$ & $\mathbf{2 0 . 2 0}$ & $\mathbf{7 . 5 9}$ & $\mathbf{6 . 5 6}$ & $\mathbf{8 . 8 8}$ \\
$1000,5 \mathrm{kyr}, 2^{\circ} \mathrm{C}$ & 44.70 & 42.16 & 47.37 & 17.34 & 15.17 & 19.61 & 7.95 & 6.65 & 9.37 \\
$1000,5 \mathrm{kyr}, 4^{\circ} \mathrm{C}$ & 35.85 & 32.59 & 38.89 & 15.66 & 13.29 & 18.15 & 8.58 & 7.10 & 10.25 \\
$1000,6 \mathrm{kyr}, 1^{\circ} \mathrm{C}$ & 48.86 & 46.78 & 51.03 & 18.52 & 16.64 & 20.37 & 7.53 & 6.52 & 8.68 \\
$1000,6 \mathrm{kyr}, 2^{\circ} \mathrm{C}$ & 44.51 & 42.11 & 47.10 & 17.50 & 15.28 & 19.77 & 7.95 & 6.61 & 9.56 \\
$1000,5 \mathrm{kyr}, 1^{\circ} \mathrm{C}$, jack5 & 49.16 & 46.12 & 51.97 & 18.48 & 16.06 & 20.80 & 7.67 & 6.44 & 9.00 \\
$1000,5 \mathrm{kyr}, 1^{\circ} \mathrm{C}$, jack15 & 49.51 & 44.94 & 54.26 & 18.60 & 15.09 & 22.14 & 7.88 & 6.24 & 9.70 \\
$1000,5 \mathrm{kyr}, 1^{\circ} \mathrm{C}$, jack25 & 50.03 & 43.05 & 56.86 & 18.83 & 13.99 & 24.32 & 8.34 & 6.19 & 10.85 \\
$1000,5 \mathrm{kyr}, 1^{\circ} \mathrm{C}$, jack35 & 51.54 & 41.20 & 62.25 & 19.75 & 12.61 & 27.59 & 9.24 & 6.28 & 12.55 \\
\hline
\end{tabular}

from $4{ }^{\circ} \mathrm{C}$ (up to $6^{\circ} \mathrm{C}$ ), the modeled SST anomalies range irrespective of season or time slice rarely from more than $1^{\circ} \mathrm{C}$. This pattern is clearly seen in the comparison of the variances of the anomalies in proxy data and model results (Table 4). However, we determined whether or not the proxy pattern for each time slice can be considered as a significant deviation from "no change", by calculating the error ranges of the anomalies. In $55.6 \%$ of all cases, zero is part of the confidence interval of the anomaly, meaning that in these cases the direction of the anomaly cannot be estimated accurately. 
Table 4. Correlation coefficients and Cohen's $\kappa$ values between the proxy and model SST anomalies for the three MIS11 time slices (Fig. 7), as well as a comparison of variances in the proxy and model data (statistically significant values are given in italics).

\begin{tabular}{|c|c|c|c|c|c|c|c|c|c|c|}
\hline \multirow[b]{2}{*}{$\begin{array}{l}\text { Temperature } \\
\text { anomaly }\end{array}$} & \multicolumn{3}{|c|}{ Correlation } & \multicolumn{3}{|c|}{ Cohen’s Kappa } & \multicolumn{4}{|c|}{ Variance } \\
\hline & $r / \rho$ & $p$ value & $\begin{array}{l}\text { Correlation } \\
\text { method }\end{array}$ & $\kappa$ & $\begin{array}{l}\text { Agreement } \\
\text { quality } \\
\text { (Altman, 1991) }\end{array}$ & $p$ value & $\begin{array}{r}\text { Variance } \\
\text { proxy } \\
\text { data }\end{array}$ & $\begin{array}{r}\text { Variance } \\
\text { model } \\
\text { data }\end{array}$ & $F$ value & $p$ value \\
\hline $390-400 \mathrm{ka}$ annual & 0.080 & 0.648 & Spearman & -0.145 & poor & 0.265 & 0.65 & 0.07 & 9.06 & $<0.0001$ \\
\hline $390-400$ ka summer & 0.509 & 0.052 & Spearman & 0.312 & fair & 0.185 & 0.84 & 0.18 & 4.76 & 0.0061 \\
\hline 390-400 ka winter & 0.382 & 0.065 & Spearman & -0.013 & poor & 0.645 & 1.88 & 0.09 & 22.06 & $<0.0001$ \\
\hline $400-410 \mathrm{ka}$ annual & -0.032 & 0.855 & Spearman & 0.005 & slight & 0.971 & 0.59 & 0.02 & 37.19 & $<0.0001$ \\
\hline $400-410$ ka summer & 0.036 & 0.903 & Spearman & -0.235 & poor & 0.283 & 1.57 & 0.03 & 57.56 & $<0.0001$ \\
\hline $400-410$ ka winter & 0.466 & 0.021 & Spearman & 0.204 & fair & 0.251 & 2.48 & 0.03 & 89.00 & $<0.0001$ \\
\hline $410-420 \mathrm{ka}$ annual & -0.073 & 0.675 & Pearson & -0.201 & poor & 0.160 & 1.16 & 0.05 & 23.85 & $<0.0001$ \\
\hline $410-420$ ka summer & 0.592 & 0.020 & Pearson & 0.500 & moderate & 0.025 & 0.38 & 0.11 & 3.38 & 0.0297 \\
\hline $410-420 \mathrm{ka}$ winter & 0.094 & 0.661 & Spearman & -0.026 & poor & 0.883 & 1.81 & 0.08 & 23.19 & $<0.0001$ \\
\hline
\end{tabular}

But notwithstanding the striking differences in the amount of SST change at the studied sites between the proxy data and the model, the direction of change and the regional patterns of anomalies show a number of similarities.

We have tested the validity of our seasonal attribution of the SST records with two randomization tests showing that none of the resulting correlation coefficients was equal to or larger than the one we originally observed when using the complete data set (Fig. S4). When using a reduced data subset of 30 records, only $1.4 \%$ of the resulting correlation coefficients were equal to or higher than the one originally observed. We can thus state that our observed correlation cannot be significantly enhanced by disregarding the season assignment of the proxy data. It is therefore reasonable to assume that the season assignment is correct and does not bias our results. On this basis, the comparison between the proxy-based and modeled SST anomalies in MIS11 (Fig. 6) shows a generally better agreement for the boreal summer than for the boreal winter. For the boreal summer, a robust trend to colder (390-400 ka) and warmer temperatures (400-410 and 410$420 \mathrm{ka}$ ) can be observed for the northernmost Atlantic region (Fig. 6). Modeled positive SST anomalies in the (sub)tropics during the 390-400 ka time interval only partly agree with the SST anomalies recorded in the sediments, while negative SST anomalies modeled for the Southern Ocean region are in better accordance with the proxy data for this time slice. The general temperature increase simulated for the 400-410 ka time slice during the boreal summer season is also reflected by the positive SST anomalies in the proxy records except for one record in the tropical Pacific and the northernmost Atlantic. A modeled temperature increase in the Northern Hemisphere accompanied by a temperature decrease in the (sub)tropics can also be observed in the proxy data for the 410-420 ka interval, especially for the Atlantic Ocean and the South China Sea. For the tropical Pacific, the Caribbean Sea, and for two South Atlantic sites, the proxy data show opposite trends to the model data (Fig. 6).
The modeled negative SST anomalies in the Southern Hemisphere for the boreal winter season for the 390-400 ka time slice generally agree well with the proxy data, while model and proxy data for the (sub)tropical regions as well as the Northern Hemisphere partly show opposite trends. The simulated SST increase in the Northern Hemisphere and the (sub)tropics accompanied by negative anomalies in the Southern Hemisphere during the 400 to $410 \mathrm{ka}$ time interval can also be observed from the proxy data for the Atlantic and Southern Ocean regions, while the observations disagree with the model data for the tropical Pacific (Fig. 6). Modeled positive SST anomalies in the Southern Hemisphere and negative temperature anomalies in the (sub)tropics are in agreement with most of the proxy records of the 410-420 ka interval, too, while, particularly in the North Atlantic, model and proxy data show opposite trends.

Despite the apparently good qualitative agreement between model and proxy data (Fig. 6), a quantitative comparison shows a different picture (Fig. 7, Table 4). A statistically significant correlation between proxy and model anomalies can only be observed for the boreal winter of the 400-410 ka time interval and for the summer of the 410-420 ka interval, with $\rho=0.47(p=0.021)$ and $r=0.59(p=0.020)$, respectively. For all other time slices, the seasonal and annual SST anomalies show low correlations between proxy and modeled data (Table 4, Fig. 7). Cohen's $\kappa$, which was used to test whether or not the proxy and modeled data are qualitatively in agreement, shows a moderate and significant $(p=0.025)$ agreement for boreal summer during the 410-420 ka interval. Fair agreement is given for the boreal summer during the $390-400 \mathrm{ka}$ and for the boreal winter during the 400-410 ka time intervals, respectively, whereby these agreements are not statistically significant, with $p$ values ranging between 0.185 and 0.251 (Table 4). 


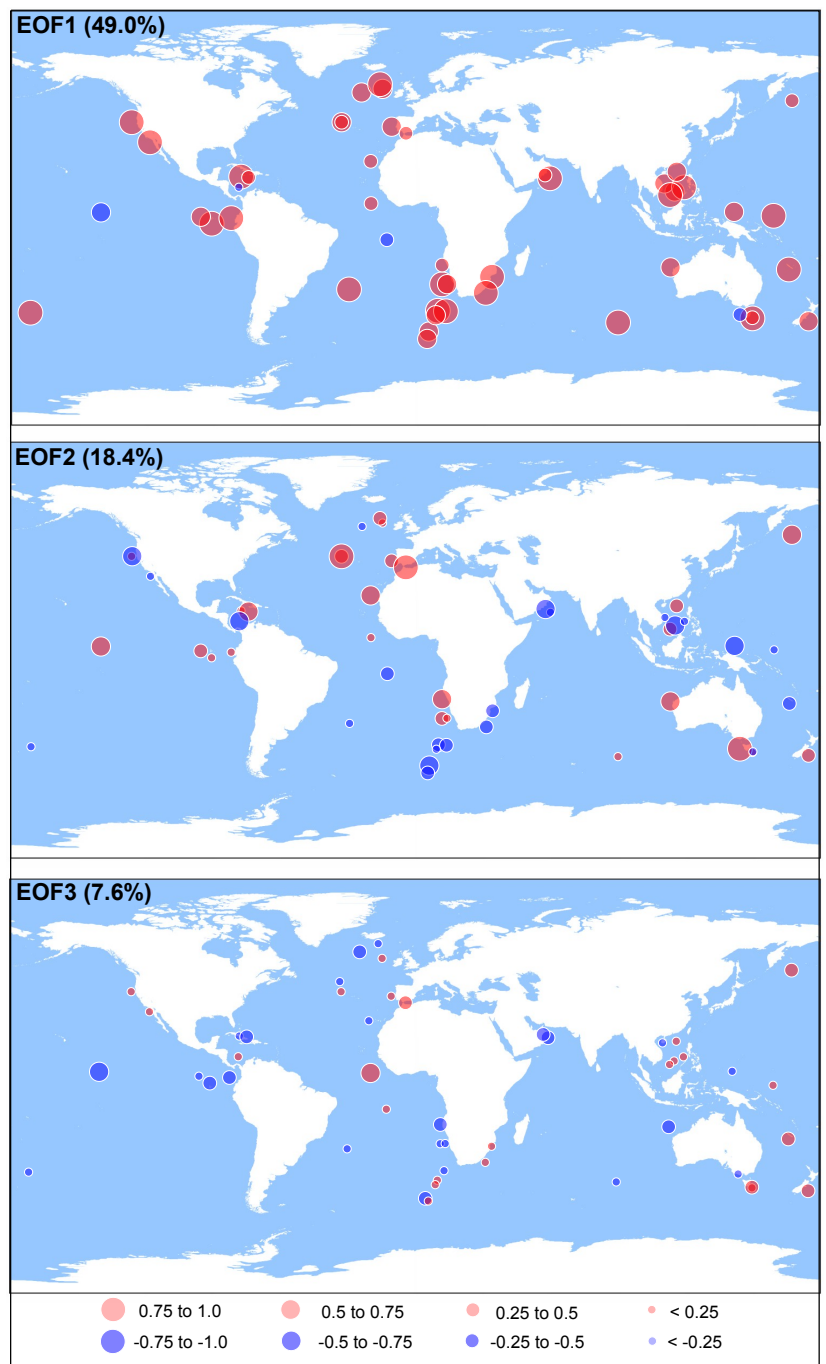

Fig. 5. Spatial distribution of the mean loadings of the first three EOFs, based on 1000 iterations using an age and a temperature uncertainty of $5 \mathrm{kyr}$ and $1^{\circ} \mathrm{C}$. Positive loadings are given in red, negative loadings in blue. Variance explained by each component is given in brackets. Almost all records show high positive loadings on the first EOF, while high positive loadings on the second EOF are restricted to the North Atlantic Ocean and the Mediterranean Sea, and south of Australia.

\section{Discussion}

\subsection{Global and regional climate trends in the proxy SST records}

Under the limitation of the uncertainty in the alignment of the benthic oxygen isotope stack with insolation as carried out by Lisiecki and Raymo (2005), it is possible to explore the relationship between insolation forcing and the global SST pattern during MIS11 as revealed by the EOF1 scores (Fig. 8a). Such a comparison is justified, because the SST records at each site are co-registered with the stable oxygen isotope variations used to align the records temporarily but are in all cases entirely independent of these. This comparison reveals a rapid global temperature rise during Termination V occurring between 430 and $425 \mathrm{kyr}$. The highest global temperatures during MIS11 were reached at around $411 \mathrm{kyr}$ when the high-latitude summer insolation was at its minimum. The SST cooling trend into the glacial inception started at around $405 \mathrm{kyr}$, corresponding to the onset of icesheet growth as indicated by benthic isotopes and the Red Sea sea-level curve (Fig. 8d).

Across MIS11, the first EOF1 follows a consistent glacialinterglacial pattern with cold SSTs during MIS12 (> 430 ka) and MIS10 $(<370 \mathrm{ka})$, and a relatively long duration of warmer SSTs from 416 to $405 \mathrm{kyr}$. A similar trend is reflected in the Antarctic temperature change based on the deuterium record of the EPICA Dome C ice core (Jouzel et al., 2007) (Figs. 8b and 9b). However, the position of the interglacial temperature peak is offset with a temperature peak in the Antarctic record lagging the EOF1 signal as well as the mean global temperature peak calculated from all records (not shown here) by $\sim 4$ kyr (Figs. $8 \mathrm{~b}$ and 10 ). The EOF1 signal is similar to mean relative SST changes in the South Atlantic and the Southern Ocean (Fig. 8b), while North Atlantic records with high loadings to EOF1 are characterized by a slower temperature decrease during the late MIS11 period - a pattern more similar to the $\mathrm{CO}_{2}$ record measured in the Dome C Antarctic ice core (Siegenthaler et al., 2005) (Figs. $8 \mathrm{c}$ and 9a). Compared to the $\delta^{18} \mathrm{O}$ sea-water record of ODP Site 1123 as a proxy for ice volume (Elderfield et al., 2012), it seems that the deglacial SST rise indicated by EOF1 preceded the reduction of the global ice volume by $\sim 5 \mathrm{kyr}$ (Fig. 8d, e). This pattern remains even when the sea level development during MIS11 is approximated by the Lisiecki and Raymo (2005) stack or by the Red Sea stable isotope record by Rohling et al. (2009) (Figs. 8d, 9c and d), indicating a faster reaction of the surface ocean to insolation and greenhouse gas forcing than that of the slowly melting ice sheets.

The temporal resolution of our study and the level of temporal uncertainty make it difficult to address the phasing of different proxies during MIS11 at millennial timescales, but we note that the global SST trend indicated by EOF1 scores does not precede $\mathrm{CO}_{2}$ (Fig. 8c). Further, the observed lag between the global SST peak and the temperature peak over Antarctica of around $4 \mathrm{kyr}$ is robust to dating uncertainties (Figs. 8b, 10). This would indicate that during the interglacial, temperature over Antarctica was not as closely coupled to the global mean as during the deglaciation, perhaps reflecting more strongly the antiphased Southern Hemisphere insolation pattern (Laepple et al., 2011).

The second EOF scores in our analysis follow a trend that differs from the global pattern and indicate a later establishment of a relative temperature maximum and a longerlasting period of warmer temperatures during late MIS11 and into MIS10 (Fig. 8e and f). This regional trend is primarily reflected in the SST records of the mid-latitude North 

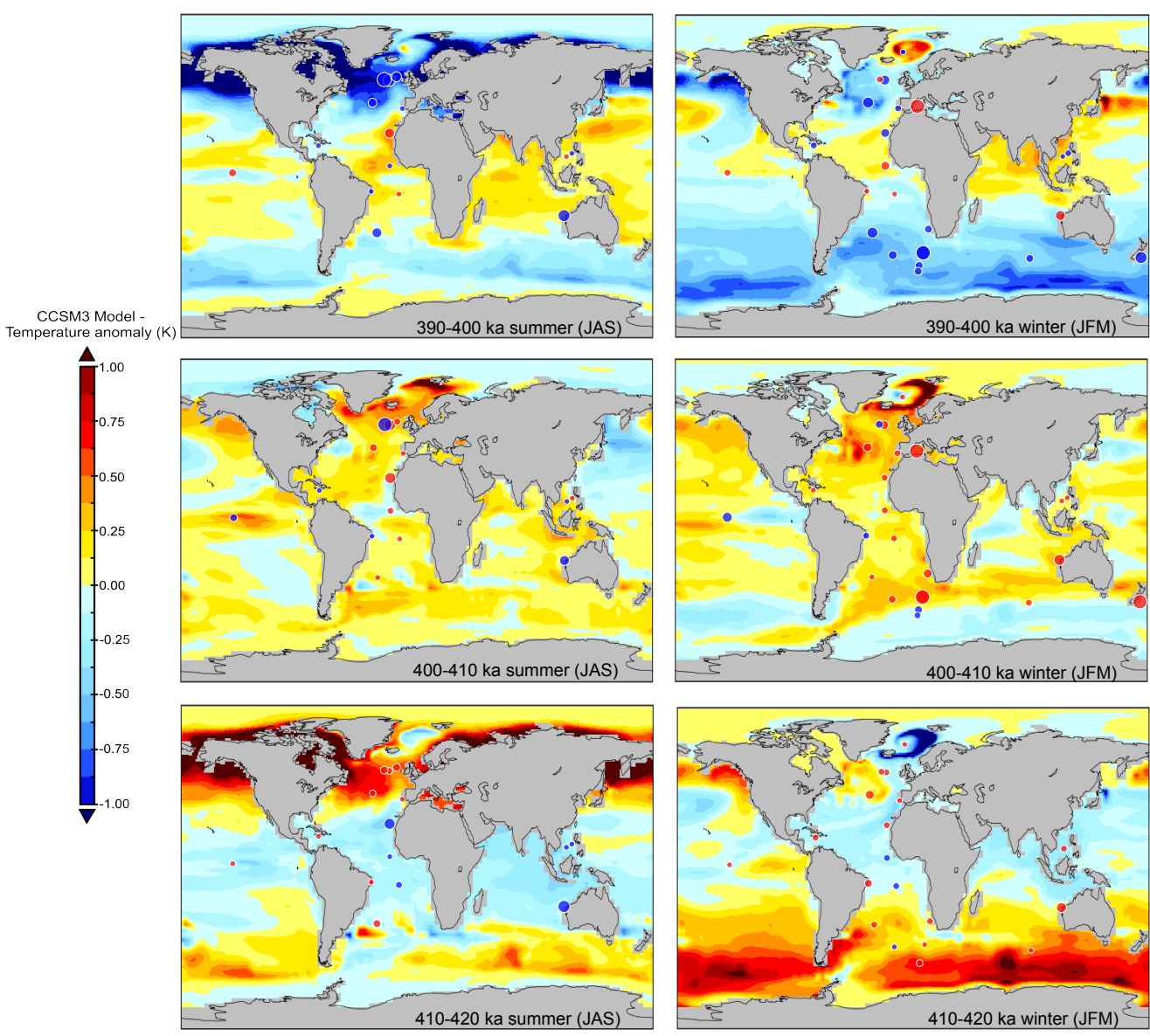

SST anomaly (K)

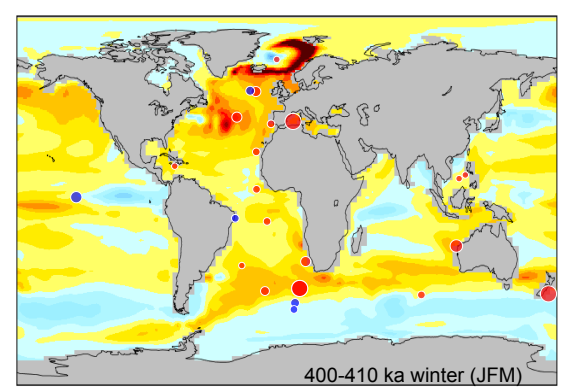

wer limit upper lim

$2.00 \bigcirc 5.00$

$1.75 \bigcirc 2.00$

$1.50 \bigcirc 1.75$

$1.25 \bigcirc 1.50$

$1.00 \bullet 1.25$

$0.75 \bullet 1.00$

$0.50 \odot 0.75$

$0.25 \bullet 0.50$

$0.00 \bullet 0.25$

$0.00 \cdot-0.25$

$-0.25 \bullet-0.50$

$-0.50 \bullet-0.75$

$-0.75 \bullet-1.00$

$-1.00-1.25$

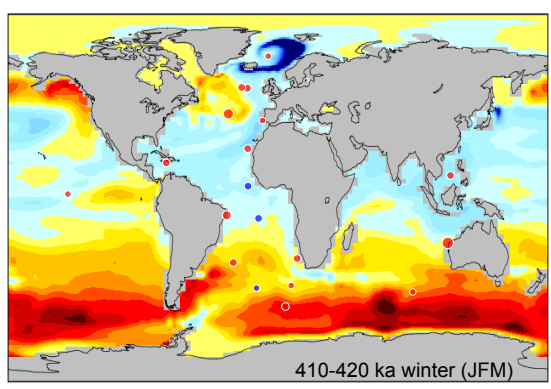

$-1.25 \bullet-1.50$

$-1.50 \bullet-1.75$

$-1.75-2.00$

$-2.00-6.00$

Fig. 6. A comparison of the boreal summer and winter sea surface temperature anomalies of proxy records with CCSM3 climate model results for 390-400, 400-410 and 410-420 ka time slices. Color and size scales indicate the magnitude of temperature anomalies relative to the mean SST of the three time slices.

Atlantic, the Mediterranean Sea as well as in one record south of Australia (Fig. 5). A similar trend, with delayed onset of interglacial conditions after Termination $\mathrm{V}$ and a longer-lasting interglacial optimum, has been recently reported also from the eastern Mediterranean (Maiorano et al., 2013). The apparent later onset of MIS11 optimum and the longer duration of interglacial warmth have been also noted by the authors of the individual records included in our compilation, particularly for records from the North Atlantic region. These authors hypothesized that the persistence of the northern ice sheets throughout MIS11 may have led to a dominant negative mode of the North Atlantic Oscillation (NAO) (Kandiano et al., 2012) whilst the associated sustained meltwater input in the (sub-)polar regions may have resulted in a less stable Atlantic meridional overturning circulation (AMOC; Voelker et al., 2010). In either case, these phenomena would lead to a reduced ocean heat transfer into the North Atlantic, causing a delayed optimum in the SST trends. Indeed, Dickson et al. (2009) conclude that a stronger AMOC during MIS11 was first established at $415 \mathrm{ka}$. Similarly, mean $\delta^{13} \mathrm{C}$ of benthic Foraminifera from water depths between 1100 and $2300 \mathrm{~m}$ in the North Atlantic that can be used as a proxy for NADW production (Lisiecki et al., 2008) shows increasing values from 425 to $405 \mathrm{ka}$, where the heaviest values were reached before only slightly decreasing until the end of MIS11 (Fig. 8f). This trend, which is indicative for enhanced NADW production between 410 and $400 \mathrm{ka}$, is quite similar to our EOF2 scores as well as to the mean relative temperature anomaly trends found in the records with high EOF2 loadings (Fig. 8e and f). The persistence of longer-lasting warmer temperatures in the terrestrial high northern latitudes in the late MIS11 and into MIS10 has also been explained by a weaker Siberian High pressure system during times of insolation minima due to lower ice and snow accumulation rates, leading to weakened East Asian winter monsoon (EAWM) as reflected by the GT32 grain size distribution in Chinese loess sequences (Hao et al., 2012) showing a similar pattern to our EOF2 signal (Fig. 8f). However, other terrestrial records from lakes Baikal and El'gygytgyn (Propopenko et al., 2010; D' Anjou et al., 2013) do not show a longer-lasting warm phase during MIS11 in the northern 

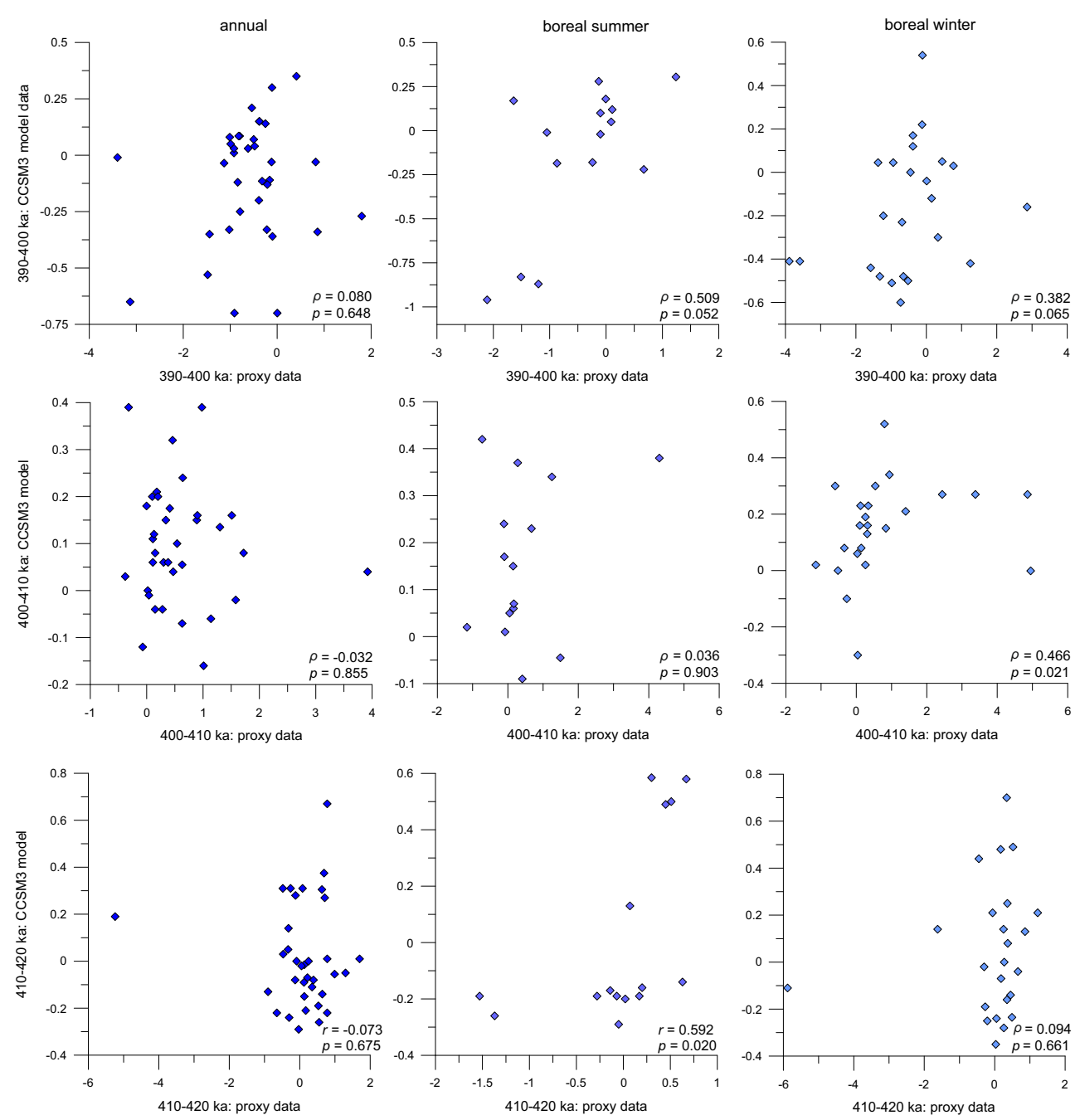

Fig. 7. Correlations between the proxy SST anomalies (annual, boreal summer and boreal winter) (in kelvin) and the model SST anomalies (in kelvin) for 390-400, 400-410 and 410-420 ka time slices. Given are the Pearson $(r)$ and Spearman $(\rho)$ correlations and $p$ values (Table 4). Higher positive correlations between the proxy and model data can be observed for the boreal summer seasons of the 390-400 and 410-420 ka time slices and for the boreal winter season of the 400-410 ka time slice. Note different $x$ and $y$ axes scaling.

higher latitudes as observed by Hao et al. (2012) and our study.

\subsection{Comparison of the climate variability between proxy and model SST}

The observation of a much lower variance in modeled temperature trends when compared to paleo-data (Table 4) has been found in other studies where marine and terrestrial proxy have been compared with simulated temperature trends for the Holocene period (Brewer et al., 2007; Zhang et al., 2010; Sundqvist et al., 2010; O'ishi and Abe-Ouchi, 2011; Lohmann et al., 2013). In principle, such disagreement might be caused by an underestimation of temperature changes in climate models, as also suggested by, for example, Brewer et al. (2007), O'ishi and Abe-Ouchi (2011) and
Lohmann et al. (2013), by an overestimated proxy SST variability, or a combination of both. Underestimation of climate variability in model simulations may be caused by shortcomings in the model physics (e.g., subgrid-scale parameterizations associated with clouds in the atmosphere or mixing in the ocean) and/or missing climate components (e.g., continental ice sheets) resulting in a lack of potentially important feedback mechanisms. At single sites, undersimulated SST variance may also be caused by too coarse grid resolution, such that, for example, shifts in oceanic fronts or upwelling zones are not resolved. Higher variance in the proxy data may result from noise and calibration uncertainties, or from uncertainties in seasonal and/or vertical attribution in the proxy records, as also suggested by Brewer et al. (2007) and Sundqvist et al. (2010) as well as from a different temporal SST resolution. The latter phenomenon, however, should 

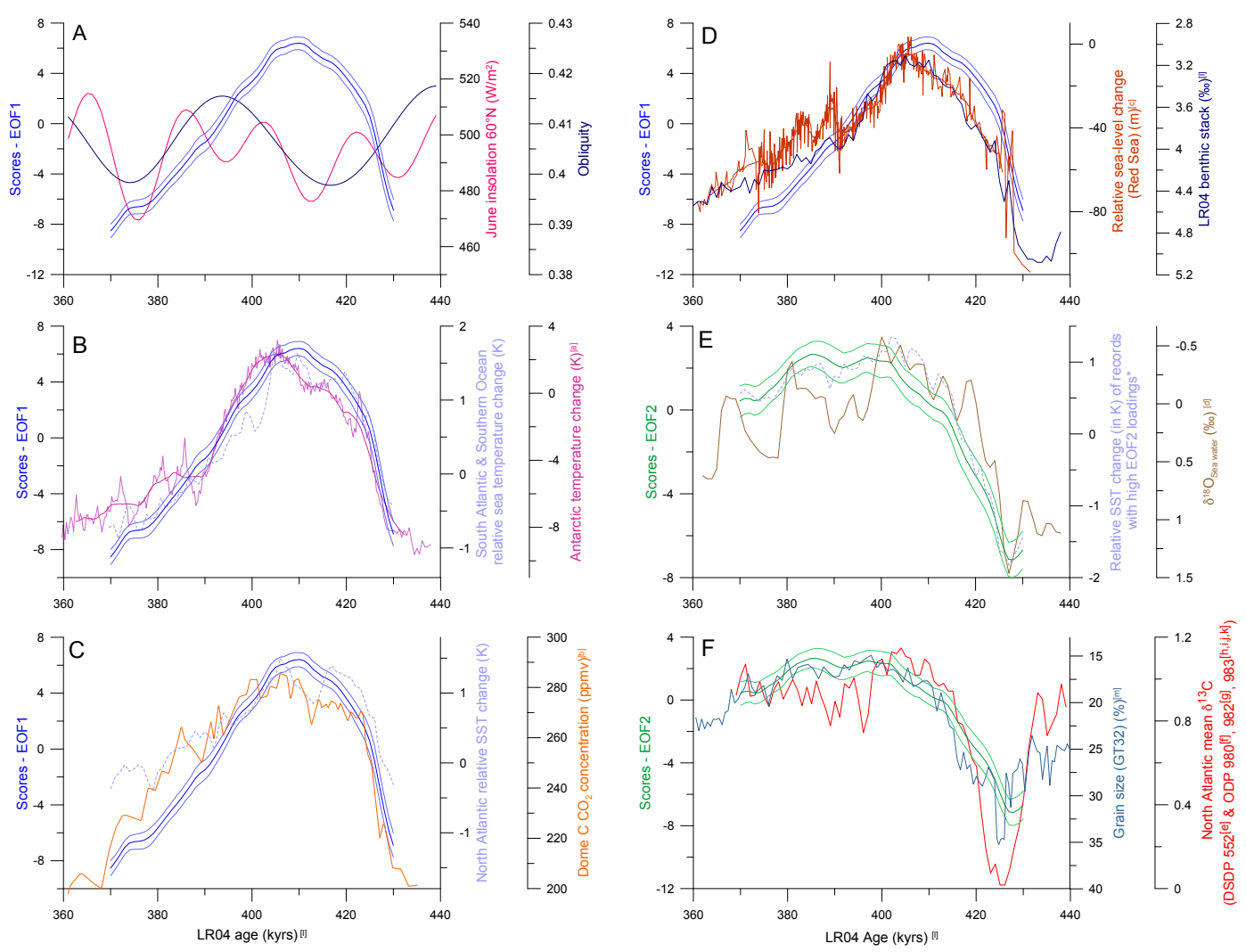

Fig. 8. Scores of the first EOF with their confidence intervals versus (A) orbital parameter (June insolation at $60^{\circ} \mathrm{N}$ and obliquity (Laskar et al., 2004)), (B) relative temperature changes in the South Atlantic and Southern Ocean and Antarctic temperature changes recorded in the Dome C ice core during MIS11 (Jouzel et al., 2007; [a]) (thin pink line: original data; thick pink line: smoothed curve), (C) mean relative temperature change in the North Atlantic records with high loadings to the first EOF and $\mathrm{CO}_{2}$ concentration recorded in the Dome $\mathrm{C}$ ice core from the Antarctic (Siegenthaler et al., 2005; [b]), and (D) relative sea-level changes in the Red Sea (Rohling et al., 2009; [c]) and the LR04 benthic stack (Lisiecki and Raymo, 2005; [1]). Scores of the second EOF mean relative temperature changes in records with high positive loadings $(>0.75)$ on the second EOF versus $(\mathbf{E}) \delta^{18} \mathrm{O}$ of sea water as proxy for ice volume (Elderfield et al., 2012; [d]), and (F) mean $\delta^{13} \mathrm{C}$ values in the North Atlantic as a proxy for North Atlantic deep water (NADW) strength and the East Asian winter monsoon signal as reflected by the GT32 grain size (content of $>32 \mu \mathrm{m}$ particles) in loess sequences (Hao et al. 2012; [m]; note inverse scale). For the mean of $\delta^{13} \mathrm{C}$ North Atlantic, records between 1100 and $2300 \mathrm{~m}$ water depth were selected according to Lisiecki et al. (2008). The $\delta^{13} \mathrm{C}$ records used here are from Shackleton and Hall (1984) [e], Oppo et al. (1998) [f], Venz et al. (1999) [g], Raymo et al. (1998) [h], McIntyre et al. (1999) [i], Kleiven et al. (2003) [j], and Raymo et al. (2004) [k]. The EDC ages of the records from the Dome $\mathrm{C}$ ice core in (B) and (C) were converted into LR04 ages (Lisiecki and Raymo, 2005; [1]) according to Parrenin et al. (2007). (*) Records with high EOF2 loadings are from IODP Site U1313 \& ODP Site 958 (North Atlantic), ODP Site 975 \& ODP Site 976 (Mediterranean Sea) and ODP Site 1168 (south of Australia).

lead to a lowering of proxy variance with record resolution (assuming that the records are all subsampling a signal with similar spectral properties).

In order to explore the potential causes of variance in the SST reconstructions by proxies, we plot SST variance against sampling resolution for all records using the proxymodel comparison (Fig. 11). The majority (eight) of the SST records with higher variability (Fig. 11) were reconstructed with the modern analog technique (MAT) and other transfer functions applied on microfossils such as radiolarians, diatoms and Foraminifera. The main assumptions when using microfossils for past SST estimates via transfer functions are that (1) the microfossil composition that is used to create a transfer function is systematically related to SST and
(2) the ecology of the microfossil assemblages has not significantly changed since the time of interest. The presence of a variable SST during the MIS11 indicated by these methods thus could reflect the effects of nuisance parameters on the reconstructed SST or large shifts in the ecology of the microfossils. The latter seems unlikely on the timescale of one glacial cycle (although changes in seasonality and vertical habitats could have occurred and affected geochemical proxies), but the former could indeed be significant, especially where the fossil assemblages differed from the calibration data set, resulting in the detection of very different modern analogs with small changes in the assemblages. On the other hand, regression-based transfer function methods, such as the MAT and the Imbrie-Kipp method, are unlikely to yield SST 

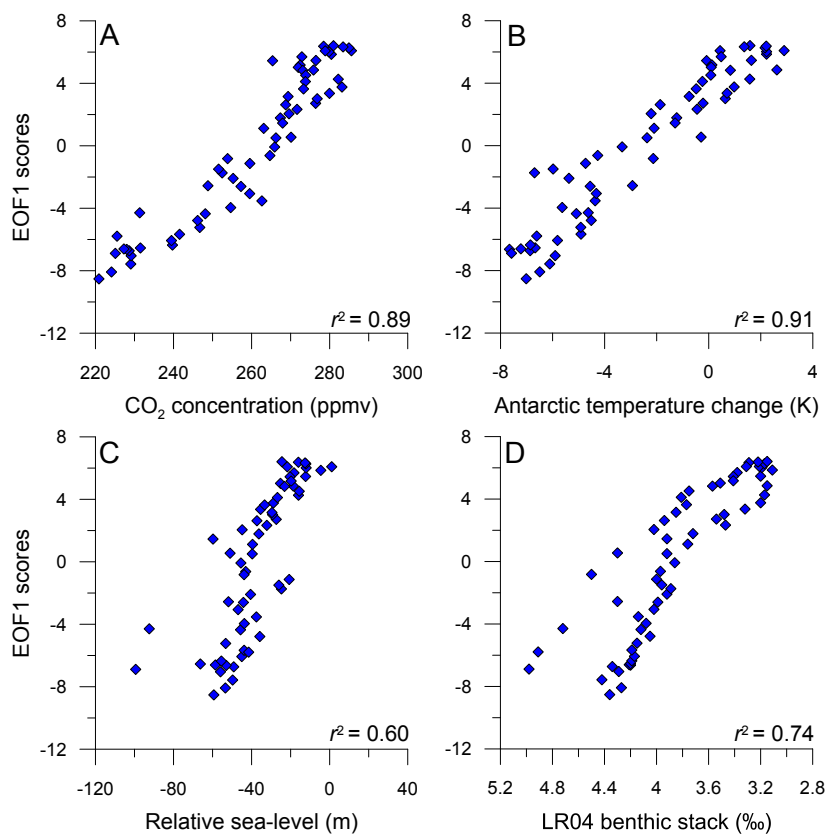

Fig. 9. Cross plots showing the correlation between EOF1 scores and (A) atmospheric $\mathrm{CO}_{2}$ concentration (Siegenthaler et al., 2005), (B) Antarctic temperature change (Jouzel et al., 2007), (C) Red Sea relative sea level change (Rohling et al., 2009) and (D) the benthic LR04 stack (Lisiecki and Raymo, 2005). EDC ages of the Antarctic temperature record were converted into LR04 ages according to Parrenin et al. (2007).

reconstructions with variance inflating the level of variance in the assemblage data. In our case, SST records based on MAT yield, for records with similar resolution, similar variance (Fig. 11), indicating that the variance of the reconstructions is unlikely to have been inflated due to the presence of no-analog faunas. In individual cases, the high variance in SST reconstructions by proxies can be attributed to nuisance variables. For example, Becquey and Gersonde (2002) concluded that carbonate dissolution may result in an over- or underestimation of SSTs when using Foraminifera with varying dissolution resistance for the application of transfer functions. These authors further conclude that their summer SSTs estimated with MAT for core PS2489 (used in this study) are overestimated by $6-7^{\circ} \mathrm{C}$ for a short interval within MIS11. Whether or not the same can be said for all records in this study remains unclear.

Despite the large differences in variance and considering all the potential sources of uncertainty in the proxy-based SST values, it is remarkable that in several cases not only a visual agreement between the direction of SST change implied by data and models is similar, but also a positive relationship between the values of SST anomalies from both approaches can be observed (Figs. 6 and 7). Whereas it is likely that many of the proxies used could produce SST reconstructions systematically shifted from their a priori sea-

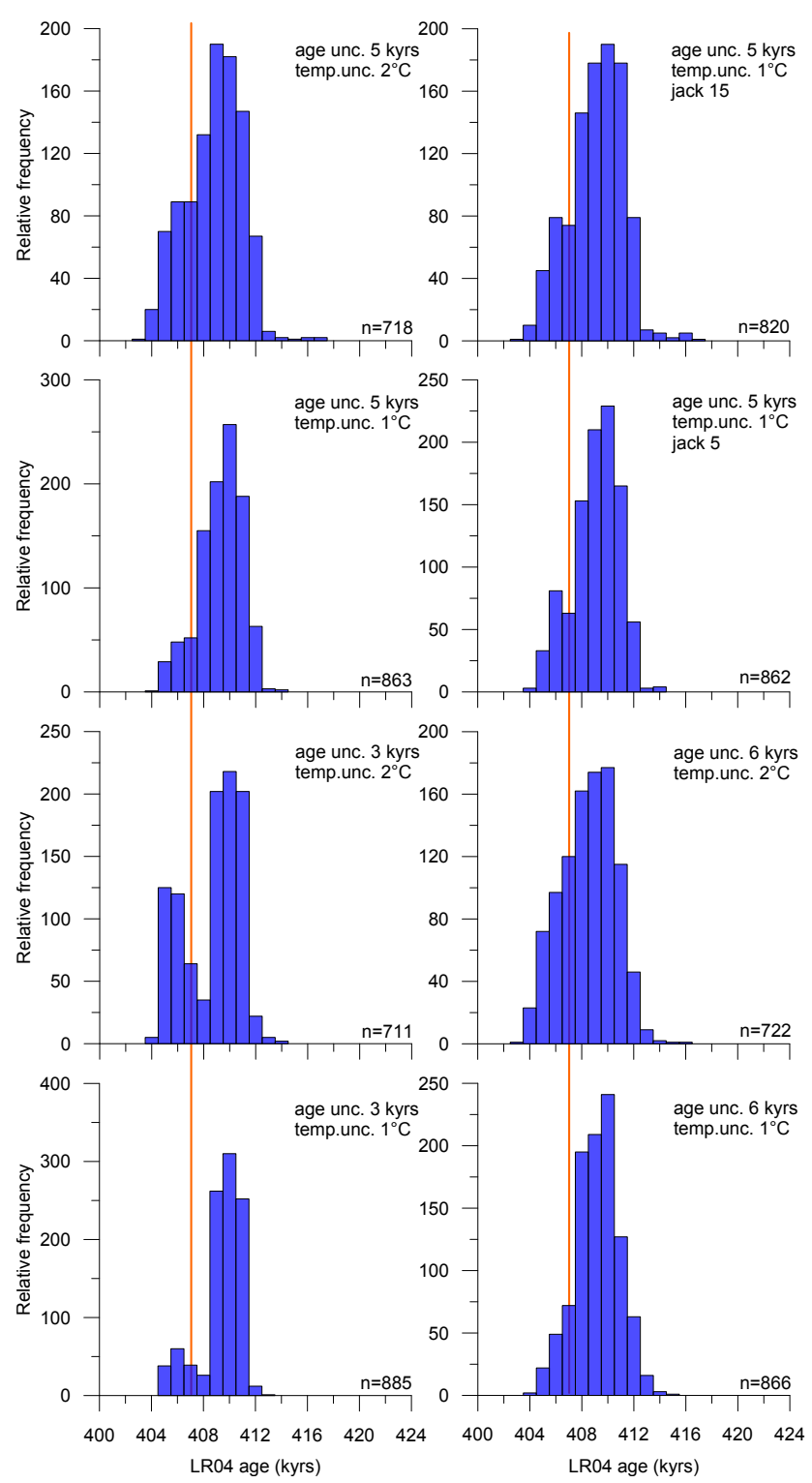

Fig. 10. Sea surface temperature optima during MIS11 calculated with various EOF analyses based on age and temperature uncertainties of 3-6 ka and $1-2{ }^{\circ} \mathrm{C}$, respectively, and jackknifing versus temperature optimum observed in Antarctica (Jouzel et al., 2007) showing a lag of $\sim 4 \mathrm{kyr}$ between the SST optimum calculated with EOF1 and the Antarctic temperature optimum during MIS11. Most EOF runs (74-89\%) given here as numbers $(n)$ show an earlier SST optimum than that recorded in Antarctica. EDC ages of the Antarctic temperature record were converted into LR04 ages according to Parrenin et al. (2007).

sonal or vertical attribution, the calculation of SST anomalies between the investigated time slices should largely reduce this problem, as long as the shifts in species ecology causing such misattribution remain temporarily stable. Apparently, especially for the boreal summer season reconstructions, the signal in the proxy-based SST anomalies resonated with 


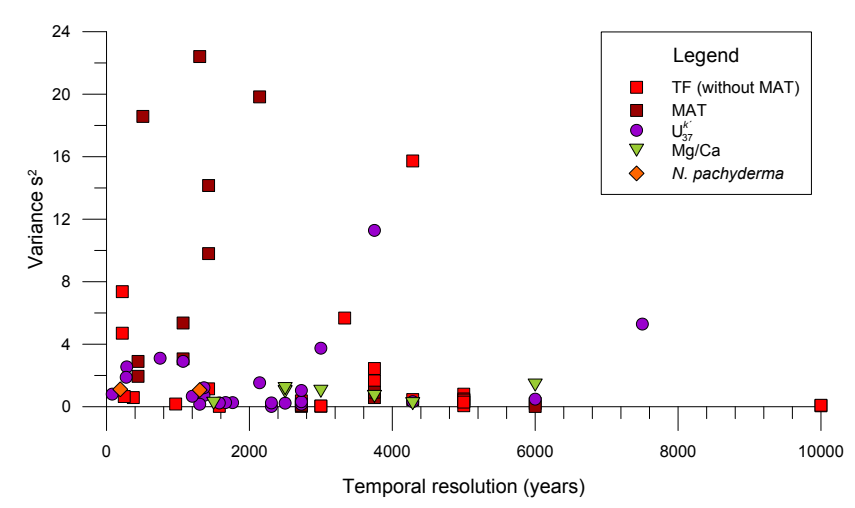

Fig. 11. Variances of the proxy SST records versus their temporal resolution. High variances in the SSTs are found in low-resolution records particularly estimated with the modern analog technique while most of the other records show lower variances with higher resolution.

processes captured by the CCSM3 model runs. Since these model runs differ mainly by orbital parameters (with greenhouse gas concentrations being largely similar, Table 2), it appears that orbital forcing has left a detectable signature in the global SST pattern during MIS11, despite its unusually low magnitude.

\section{Conclusions}

Using a compilation of SST records from 57 sites, aligned to a common timescale through oxygen isotope stratigraphy, and a series of CCSM3 model runs forced by greenhouse gas concentrations and orbital parameters, we investigated global patterns of MIS11 SST and their correlation with forcing mechanisms.

- An empirical orthogonal function analysis of 48 SST records revealed the presence of two main SST trends, which collectively explained nearly three quarters of the variation in the data set. We have shown that the results of this analysis are robust against sample selection and errors in the age model, but are more sensitive to SST uncertainty.

- The main SST trend describes the global glacialinterglacial pattern, showing rapid deglaciation followed by a broad climatic optimum culminating around $410 \mathrm{ka}$. The SST development during MIS11 optimum is not in phase with Antarctic temperature and $\mathrm{CO}_{2}$. This lag is the dominant signal in the second EOF. We speculate that this phase difference, which is most strongly manifested in the North Atlantic, may be explained by a later establishment of a stable AMOC in MIS11.

- The second EOF further differs from the global SST trend by a protracted warmer period during MIS11, lasting into MIS10. This regional trend may reflect not only a later onset but also a longer duration of a stable North Atlantic AMOC during MIS11.

- The comparison of the CCSM3 model with the proxy data shows that similar temperature trends can be found especially for the summer seasons. It further shows that the SST variability found in the proxy data is significantly higher than in the model. This is more likely a consequence of an underestimation of SST changes in climate models. Alternatively, SST reconstructions for MIS11 would have to be subject to pervasive influence of nuisance parameters, which vary at millennial timescales. The general agreement between proxy-derived and modeled SST anomalies indicates the MIS11 climate was responding to insolation forcing, despite the low orbital eccentricity.

\section{Supplementary material related to this article is available online at http://www.clim-past.net/9/2231/2013/ cp-9-2231-2013-supplement.zip.}

Acknowledgements. We are grateful to the following colleagues for providing their data sets: T. Bickert, K. Billups, P. De Deckker, P. Dekens, H. Elderfield, J. M. Gonzales Donoso, B. W. Hayward, C. Hillaire-Marcel, E. Kandiano, K. Lawrence, D. Lea, L. T. Li, D. Nürnberg, F. Peeters, C. Pelejero, M.-S. Poli, S. Sepulcre, K.-J. Wei, J. Cheng, and M. Ziegler. We thank A. Voelker and an anonymous reviewer for their comments that helped improve the manuscript. We further thank A. Govin for her helpful comments. The study was funded by the Deutsche Forschungsgemeinschaft (DFG) through the Priority Programme INTERDYNAMIC. CCSM3 simulations were performed on the SGI Altix supercomputer of the Norddeutscher Verbund für Hochund Höchstleistungsrechnen (HLRN). The presented data used for EOF analyses and the CCSM3 model data will be available on the PANGAEA database (www.pangaea.de).

Edited by: U. Herzschuh

\section{References}

Altman, D. G.: Practical Statistics for Medical Research, CRC Texts in Statistical Science, Chapman\&Hall, Boca Raton, 1991.

Bard, E. and Rickaby, R. E. M.: Migration of the subtropical front as a modulator of glacial climate, Nature, 460, 380-384, 2009.

Barker, S., Cacho, I., Benwayc, H., and Tachikawa, K.: Planktonic foraminiferal $\mathrm{Mg} / \mathrm{Ca}$ as a proxy for past oceanic temperatures: a methodological overview and data compilation for the Last Glacial Maximum, Quaternary Sci. Rev., 24, 821-834, 2005.

Bauch, H. A., Erlenkeuser, H., Helmke, J. P., and Struck, U.: A paleoclimatic evaluation of marine oxygen isotope stage 11 in the high-northern Atlantic (Nordic seas), Global Planet. Change, 24, 27-39, 2000. 
Becquey, S. and Gersonde, R.: Past hydrographic and climatic changes in the Subantarctic Zone of the South Atlantic - The Pleistocene record from ODP Site 1090, Palaeogeogr. Palaeoecl., 182, 221-239, 2002.

Becquey, S. and Gersonde, R.: A 0.55-Ma paleotemperature record from the Subantarctic zone: Implications for Antarctic Circumpolar Current development, Paleoceanography, 18, 1014, doi:10.1029/2000PA000576, 2003.

Berger, A.: Long-term variations of daily insolation and Quaternary climatic changes, J. Atmos. Sci., 35, 2362-2367, 1978.

Berger, A. and Loutre, M. F.: Insolation values for the climate of the last 10 million years, Quaternary Sci. Rev., 10, 297-317, 1991.

Braconnot, P., Otto-Bliesner, B., Harrison, S., Joussaume, S., Peterchmitt, J.-Y., Abe-Ouchi, A., Crucifix, M., Driesschaert, E., Fichefet, Th., Hewitt, C. D., Kageyama, M., Kitoh, A., Loutre, M.-F., Marti, O., Merkel, U., Ramstein, G., Valdes, P., Weber, L., Yu, Y., and Zhao, Y.: Results of PMIP2 coupled simulations of the Mid-Holocene and Last Glacial Maximum - Part 2: feedbacks with emphasis on the location of the ITCZ and mid- and high latitudes heat budget, Clim. Past, 3, 279-296, doi:10.5194/cp-3-279-2007, 2007.

Brewer, S., Guiot, J., and Torre, F.: Mid-Holocene climate change in Europe: a data-model comparison, Clim. Past, 3, 499-512, doi:10.5194/cp-3-499-2007, 2007.

Caley, T., Kim, J.-H., Malaizé, B., Giraudeau, J., Laepple, T., Caillon, N., Charlier, K., Rebaubier, H., Rossignol, L., Castañeda, I. S., Schouten, S., and Sinninghe Damsté, J. S.: High-latitude obliquity as a dominant forcing in the Agulhas current system, Clim. Past, 7, 1285-1296, doi:10.5194/cp-7-1285-2011, 2011.

Chen, M.-T., Chang, Y.-P., Chang, C.-C., Wang, L.-W., Wang, C.H., and Yu, E.-F.: Late Quaternary sea-surface temperature variations in the southeast Atlantic: a planktic foraminifer faunal record of the past $600000 \mathrm{yr}$ (IMAGES II MD962085), Mar. Geol., 180, 163-181, 2002.

Chen, M.-T., Shiau, L.-J., Yu, P.-S., Chiu, T.-C., Chen, Y.-G., and Wei, K.-Y.: 500 000-Year records of carbonate, organic carbon, and foraminiferal sea-surface temperature from the southeastern South China Sea (near Palawan Island), Palaeogeogr. Palaeocl., 197, 113-131, 2003.

Clemens, S. C. and Prell, W. J.: Oxygen and carbon isotopes from Site 1146, northern South China Sea, Proc. ODP, Sci. Results, 184, 1-8, 2003.

Clemens, S. C., Murray, D. W., and Prell, W. J.: Nonstationary phase of the Plio-Pleistocene Asian Monsoon, Science, 274, 943-948, 1996.

Cohen, J.: A coefficient of agreement for nominal scales, Educ. Psychol. Meas., 20, 37-46, 1960.

Collins, W. D., Blackmon, M. L., Bonan, G. B., Hack, J. J., Henderson, T. B., Kiehl, J. T., Large, W. G., and McKenna, D. S.: The Community Climate System Model version 3 (CCSM3), J. Climate, 19, 2122-2143, 2006.

Conte, M. H., Sicre, M.-A., Rühlemann, C., Weber, J. C., Schulte, S., Schulz-Dull, D., and Blanz, T.: Global temperature calibration of the alkenone unsaturation index (UK37) in surface waters and comparison with surface sediments, Geochem. Geophys. Geosy., 7, Q02005, doi:10.1029/2005GC001054, 2006.

Cortese, G., Abelmann, A., and Gersonde, R.: A glacial warm water anomaly in the subantarctic Atlantic Ocean, near the Agulhas Retroflection, Earth Planet. Sci. Lett., 222, 767-778, 2004.
Crundwell, M., Scott, G., Naish, T., and Carter, L.: Glacialinterglacial ocean climate variability from planktonic foraminifera during the Mid-Pleistocene transition in the temperate Southwest Pacific, ODP Site 1123, Palaeogeogr. Palaeocl., 260, 202-229, 2008.

D’Anjou, R. M., Wei, J. H., Castaneda, I. S., Brigham-Grette, J., Petsch, S. T., and Finkelstein, D. B.: High-latitude environmental change during MIS 9 and 11: biogeochemical evidence from Lake El'gygytgyn, Far East Russia, Clim. Past, 9, 567-581, doi:10.5194/cp-9-567-2013, 2013.

De Abreu, L., Abrantes, F. F., Shackleton, N. J., Tzedakis, P. C., McManus, J. F., Oppo, D. W., and Hall, M. A.: Ocean climate variability in the eastern North Atlantic during interglacial marine isotope stage 11: A partial analogue to the Holocene?, Paleoceanography, 20, PA3009, doi:10.1029/2004PA001091, 2005.

de Villiers, S.: Dissolution effects on foraminiferal $\mathrm{Mg} / \mathrm{Ca}$ records of sea surface temperature in the western equatorial Pacific, $\mathrm{Pa}-$ leoceanography, 18, 1070, doi:10.1029/2002PA000802 2003.

Dickson, A. J., Beer, C. J., Dempsey, C., Maslin, M. A., Bendle, J. A., McClymont, E. L., and Pancost, R. D.: Oceanic forcing of the Marine Isotope Stage 11 interglacial, Nat. Geosci., 2, 428-433, 2009.

Dudley, W. C. and Nelson, C. S.: The influence of non-equilibrium isotope fractionation on the Quaternary calcareous nannofossil stable isotope signal in the southwest Pacific Ocean, DSDP Site 594, Mar. Micropaleontol., 24, 3-27, 1994.

Dürkopp, A., Hale, W., Mulitza, S., Pätzold, J., and Wefer, G.: Late Quaternary variations of sea surface salinity and temperature in the western tropical Atlantic: evidence from $\mathrm{d}^{18} \mathrm{O}$ of Globigerinoides sacculifer, Paleoceanography, 12, 764-772, 1997.

Elderfield, H., Greaves, M., Barker, S., Hall, I. R., Tripati, A., Ferretti, P., Crowhurst, S., Booth, L., and Daunt, C.: A record of bottom water temperature and seawater $\mathrm{d}^{18} \mathrm{O}$ for the Southern Ocean over the past $440 \mathrm{kyr}$ based on $\mathrm{Mg} / \mathrm{Ca}$ of benthic foraminiferal Uvigerina spp., Quaternary Sci. Rev., 29, 160-169, 2010.

Elderfield, H., Ferretti, P., Greaves, M., Crowhurst, S., McCave, I. N., Hodell, D., and Piotrowski, A. M.: Evolution of ocean temperature and ice volume through the Mid-Pleistocene climate transition, Science, 337, 704-709, 2012.

Emeis, K.-C., Doose, H., Mix, A., and Schulz-Bull, D.: Alkenone sea-surface temperatures and carbon burial at Site 846 (eastern equatorial Pacific Ocean): the last 1.3 M.Y., Proc. ODP, Sci. Results, 138, 605-613, 1995.

EPICA community members: Eight glacial cycles from an Antarctic ice core, Nature, 429, 623-628, 2004.

Garidel-Thoron, T. D., Rosenthal, Y., Bassinot, F., and Beaufort, L.: Stable sea surface temperatures in the western Pacific warm pool over the past 1.75 million years, Nature, 433, 294-298, 2005.

Hale, W. and Pflaumann, U.: Sea-surface Temperature Estimations using a Modern Analog Technique with Foraminiferal Assemblages from Western Atlantic Quaternary Sediments, in: Use of Proxies in Paleoceanography - Examples from the South Atlantic, edited by: Fischer, G. and Wefer, G., Spinger, Berlin, Heidelberg, 69-90, 1999.

Hall, I. R., McCave, I. N., Shackleton, N. J., Weedon, G. P., and Harris, S. E.: Intensified deep Pacific inflow and ventilation in Pleistocene glacial times, Nature, 412, 809-812, 2001. 
Hammer, O., Harper, D. A. T., and Ryan, P. D.: PAST: Palaeontological statistics package for education and data analysis, Paleaeontol. Electron., 4, 9 pp., 2001.

Hammer, O. and Harper, D. A. T.: Paleontological Data Analysis, Blackwell Publishing, Malden, Oxford, Victoria, 2006

Hannachi, A., Jolliffe, I. T., and Stephenson, D. B.: Empirical orthogonal functions and related techniques in atmospheric science: A review, Int. J. Climatol., 27, 1119-1152, 2007.

Hao, Q., Wang, L., Oldfield, F., Peng, S., Qin, L., Song, Y., Xu, B., Qiao, Y., Bloemendal, J., and Guo, Z.: Delayed build-up of Arctic ice sheets during 400,000-year minima in insolation variability, Nature, 490, 393-396, 2012.

Haug, G. H.: Zur Paläo-Ozeanographie und Sedimentationsgeschichte im Nordwest- Pazifik während der letzten 6 Millionen Jahre (ODP-Site 882), Ph. D., MathematischNaturwissenschaftliche Fakultät, Christian-AlbrechtsUniversität, Kiel, 98 pp., 1995.

Hays, J. D., Imbrie, J., and Shackleton, N. J.: Variations in the Earth's orbit: Pacemaker of the Ice Ages, Science, 194, 11211132,1976

Hayward, B.W., Scott, G. H., Crundwell, M. P., Kennett, J. P., Carter, L., Neil, H. L., Sabaa, A. T., Wilson, K., Rodger, J. S., Schaefer, G., Grenfell, H. R., and Li, Q.: The effect of submerged plateaux on Pleistocene gyral circulation and sea-surface temperatures in the Southwest Pacific, Global Planet. Change, 63, 309316, 2008.

Healey, S. and Thunell, R.: Millenial-scale variability in western subtropical North Atlantic surface and deep water circulation during marine isotope stages 11 and 12, Paleoceanography, 19, PA1013, doi:10.1029/2003PA000925, 2004

Helmke, J. P., Bauch, H. A., and Erlenkeuser, H.: Development of glacial and interglacial conditions in the Nordic seas between 1.5 and 0.35 Ma, Quaternary Sci. Rev., 22, 1717-1728, 2003.

Herbert, T. D., Schuffert, J. D., Andreasen, D., Heusser, L., Lyle, M., Mix, A., Ravelo, A. C., Stott, L. D., and Herguera, J. C.: Collapse of the California Current during glacial maxima linked to climate change on land, Science, 293, 71-76, 2001.

Herbert, T. D., Cleaveland Peterson, L., Lawrence, K. T., and Liu, Z.: Tropical ocean temperatures over the past 3.5 million years, Science, 328, 1530-1534, 2010.

Hodell, D. A., Charles, C. D., and Ninnemann, U. S.: Comparison of interglacial stages in the South Atlantic sector of the southern ocean for the past $450 \mathrm{kyr}$ : implifications for Marine Isotope Stage (MIS) 11, Global Planet. Change, 24, 7-26, 2000.

Hodell, D. A., Charles, C. D., Curtis, J. H., Mortyn, P. G., Ninnemann, U. S., and Venz, K. A.: Data report: Oxygen isotope stratigraphy of ODP Leg 177 Sites 1088, 1089, 1090, 1093, and 1094, Proc. ODP, Sci. Results, 177, 1-26, $2003 \mathrm{a}$.

Hodell, D. A., Venz, K. A., Charles, C. D., and Ninnemann, U. S.: Pleistocene vertical carbon isotope and carbonate gradients in the South Atlantic sector of the Southern Ocean, Geochem. Geophy. Geosys., 4, 1004, doi:10.1029/2002GC000367, 2003b.

Imbrie, J. and Kipp, N. G.: A new micropaleontological method for quantitative paleoclimatology: Application to a late Pleistocene Caribbean core, in: The Late Cenozoic Glacial Ages, edited by: Turekian, K. K., Yale University Press, New Haven, Conn, 71181,1971
Jahn, B.: Mid to late Pleistocene variations of marine productivity in and terrigenous input to the southeast Atlantic, Universität Bremen, Berichte aus dem Fachbereich Geowissenschaften, 2002.

Jahn, B., Donner, B., Müller, P. J., Röhl, U., Schneider, R. R., and Wefer, G.: Pleistocene variations in dust input and marine productivity in the northern Benguela Current: Evidence of evolution of global glacial-interglacial cycles, Palaeogeogr. Palaeocl., 193, 515-533, 2003.

Jian, Z., Wang, P., Chen, M.-P., Li, B., Zhao, Q., B“uhring, C., Laj, C., Lin, H.-L., Pflaumann, U., Bian, Y., Wang, R., and Cheng, X.: Foraminiferal responses to major Pleistocene paleoceanographic changes in the southern China Sea, Paleoceanography, 15, 229243, 2000.

Jolliffe, I. T.: Principal Component Analysis, 2nd Edn., SpringerVerlag, New York, 487 pp., 2002.

Jouzel, J., Masson-Delmotte, V., Cattani, O., Dreyfus, G., Falourd, S., Hoffmann, G., Minster, B., Nouet, J., Barnola, J. M., Chappellaz, J., Fischer, H., Gallet, J. C., Johnsen, S., Leuenberger, M., Loulergue, L., Luethi, D., Oerter, H., Parrenin, F., Raisbeck, G., Raynaud, D., Schilt, A., Schwander, J., Selmo, E., Souchez, R., Spahni, R., Stauffer, B., Steffensen, J. P., Stenni, B., Stocker, T. F., Tison, J. L., Werner, M., and Wolff, E. W.: Orbital and millennial Antarctic climate variability over the past 800,000 years, Science, 317, 793-796, 2007.

Kandiano, E. S. and Bauch, H. A.: Surface ocean temperatures in the north-east Atlantic during the last 500000 years: evidence from foraminiferal census data, Terra Nova, 15, 265-271, 2003.

Kandiano, E. S. and Bauch, H. A.: Phase relationship and surface water mass change in the Northeast Atlantic during Marine Isotope Stage 11 (MIS 11), Quaternary Res., 68, 445-455, 2007.

Kandiano, E. S., Bauch, H. A., Fahl, K., Helmke, J. P., Röhl, U., Pérez-Folgado, M., and Cacho, I.: The meridional temperature gradient in the eastern North Atlantic during MIS 11 and its link to the ocean-atmosphere system, Palaeogeogr. Palaeocl., 333334, 24-39, 2012.

Kleiven, H. F., Jansen, E., Curry, W. B., Hodell, D. A., and Venz, K.: Atlantic Ocean thermohaline circulation changes on orbital to suborbital timescales during the mid-Pleistocene, Paleoceanography, 18, 1008, doi:10.1029/2001PA000629, 2003.

Kunz-Pirrung, M., Gersonde, R., and Hodell, D. A.: Mid-Brunhes century-scale diatom sea surface temperature and sea ice records from the Atlantic sector of the Southern Ocean (ODP Leg 177, Sites 1093, 1094 and core PS2089-2), Palaeogeogr. Palaeocl., 182, 305-328, 2002.

Laepple, T., Werner, M., and Lohmann, G.: Synchronicity of Antarctic temperatures and local solar insolation on orbital timescales, Nature, 471, 91-94, 2011.

Laskar, J., Robutel, P., Joutel, F., Gastineau, M., Correia, A. C. M., and Levrard, B.: A long term numerical solution for the insolation quantities of the Earth, Astron. Astrophys., 428, 261-285, 2004.

Lawrence, K. T., Liu, Z., and Herbert, T. D.: Evolution of the eastern tropical Pacific through Plio-Pleistocene glaciation, Science, 312, 79-83, 2006.

Lawrence, K. T., Herbert, T. D., Brown, C. M., Raymo, M. E., and Haywood, A. M.: High amplitude variations in North Atlantic sea surface temperature during the early Pliocene Warm Period, Paleoceanography, 24, PA2218, doi:10.1029/2008PA001669, 2009. 
Lawrence, K. T., Sosdian, S., White, H. E., and Rosenthal, Y.: North Atlantic climate evolution through the Plio-Pleistocene climate transitions, Earth Planet. Sc. Lett., 300, 329-342, 2010.

Le, J. and Shackleton, N. J.: Carbonate dissolution fluctuations in the western equatorial Pacific during the late Quaternary, Paleoceanography, 7, 21-42, 1992.

Lea, D. W., Pak, D. K., and Spero, H. J.: Climate impact of late Quaternary equatorial Pacifc sea surface temperature variations, Science, 289, 1719-1724, 2000.

Li, L., Wang, H., Li, J. R., Zhao, M., and Wang, P.: Changes in sea surface temperature in western South China Sea over the past 450 ka, Chinese Sci. Bull., 54, 3335-3343, 2009.

Li, L., Li, Q., Tian, J., Wang, P., Wang, H., and Liu, Z.: A 4-Ma record of thermal evolution in the tropical western Pacific and its implications on climate change, Earth Planet. Sc. Lett., 309, 10-20, 2011.

Lisiecki, L. E. and Raymo, M. E.: A Pliocene-Pleistocene stack of 57 globally distributed benthic d18O records, Paleoceanography, 20, PA1003, 10.1029/2004PA001071, 2005.

Lisiecki, L. E., Raymo, M. E., and Curry, W. B.: Atlantic overturning responses to Late Pleistocene climate forcings, Nature, 456, 85-88, 2008.

Liu, Z. and Herbert, T. D.: High-latitude influence on the eastern equatorial Pacific climate in the early Pleistocene epoch, Nature, 427, 729-723, 2004.

Lohmann, G., Pfeiffer, M., Laepple, T., Leduc, G., and Kim, J.-H.: A model-data comparison of the Holocene global sea surface temperature evolution, Clim. Past, 9, 1807-1839, doi:10.5194/cp-9-1807-2013, 2013.

Lourergue, L., Schilt, A., Spahni, R., Masson-Delmotte, V., Blunier, T., Lemieux, B., Barnola, J.-M., Raynaud, D., Stocker, T. F., and Chappellaz, J.: Orbital and millennial-scale features of atmospheric $\mathrm{CH}_{4}$ over the past 800,000 years, Nature, 453, 383386, 2008.

Loutre, M. F. and Berger, A.: Marine Isotope Stage 11 as an analogue for the present interglacial, Global Planet. Change, 36, 209-217, 2003.

Maiorano, P., Tarantino, F., Marino, M., and De Lange, G. J.: Paleoenvironmental conditions at Core KC01B (Ionian Sea) through MIS 13-9: Evidence from calcareous nannofossil assemblages, Quaternary Int., 288, 97-111, 2013.

Malmgren, B. A. and Nordlund, U.: Application of artificial neural networks to paleoceanographic data, Palaeogeogr. Palaeocl., 136, 359-373, doi:10.1016/s0031-0182(97)00031-x, 1997.

Malmgren, B. A., Kucera, M., Nyberg, J., and Waelbroeck, C.: Comparison of statistical and Artificial Neural Network techniques for estimating past sea surface temperatures from planktonic foraminifer census data, Paleoceanography, 16, 520-530, doi:10.1029/2000pa000562, 2001.

Martrat, B., Grimalt, J. O., Shackleton, N. J., de Abreu, L., Hutterli, M. A., and Stocker, T. F.: Four climate cycles of recurring deep and surface water destabilizations on the Iberian Margin, Science, 317, 502-507, 2007.

McIntyre, K., Ravelo, A. C., and Delaney, M. L.: North Atlantic intermediate waters in the late Pliocene to early Pleistocene, Paleoceanography, 14, 324-335, doi:10.1029/1998PA900005, 1999.

McManus, J. F., Oppo, D. W., and Cullen, J. L.: A 0.5-millionyear record of millennial-scale climate variability in the North Atlantic, Science, 283, 971-975, 1999.
Medina-Elizalde, M. and Lea, D. W.: The Mid-Pleistocene transition in the tropical Pacific, Science, 310, 1009-1012, 2005.

Merkel, U., Prange, M., and Schulz, M.: ENSO variability and teleconnections during glacial climates, Quaternary Sci. Rev., 29, 86-100, 2010.

Mix, A. C., Le, J., and Shackleton, N. J.: Benthic foraminiferal stable isotope stratigraphy of Site 846: 0-1.8 Ma, Proc. ODP, Sci. Results, 138, 839-854, 1995.

Müller, P. J., Kirst, G., Ruhland, G., Storch, I. V., and RosellMelé, A.: Calibration of the alkenone paleotemperature index U37K' based on core-tops from the eastern South Atlantic and the global ocean $\left(60^{\circ} \mathrm{N}-60^{\circ} \mathrm{S}\right)$, Geochim. Cosmochim. Ac., 62, 1757-1772, 1998.

Naafs, B. D. A., Hefter, J., Ferretti, P., Stein, R., and Haug, G. H.: Sea surface temperatures did not control the first occurrence of Hudson Strait Heinrich Events during MIS 16, Paleoceanography, 26, PA4201, doi:10.1029/2011PA002135, 2011.

Niebler, H.-S.: Rekonstruktion von Paläo-Umweltparametern anhand von stabilen Isotopen und Faunenvergesellschaftungen planktischer Foraminiferen im Südatlantik, Ber. Polarforsch., 167, 1-198, 1995.

Niitsuma, N., Oba, T., and Okada, M.: Oxygen and carbon isotope stratigraphy at Site 723, Oman Margin, Proc. ODP, Sci. Results, 117, 321-341, 1991.

Nürnberg, D. and Groeneveld, J.: Pleistocene variability of the Subtropical Convergence at East Tasman Plateau: Evidence from planktonic foraminiferal Mg/Ca (ODP Site 1172A), Geochem. Geophy. Geosys., 7, Q04P11, doi:10.1029/2005GC000984, 2006.

Nürnberg, D., Brughmans, N., Schönfeld, J., Ninnemann, U., and Dullo, C.: Paleo-export production, terrigenous flux and sea surface temperatures around Tasmania - implications for Glacial/Interglacial changes in the Subtropical Convergence Zone, in: The Cenozoic Southern Ocean: Tectonics, Sedimentation and Climate Change between Australia and Antarctica, edited by: Exon, N., Kennett, J., and Malone, M., Geophysical Monograph Series, 151, American Geophysical Union, Washington, DC, 291-318, 2004.

O'ishi, R. and Abe-Ouchi, A.: Polar amplification in the mid-Holocene derived from dynamical vegetation change with a GCM, Geophys. Res. Lett., 38, L14702, doi:10.1029/2011GL048001, 2011.

Oleson, K. W., Niu, G.-Y., Yang, Z.-L., Lawrence, D. M., Thornton, P. E., Lawrence, P. J., Stöckli, R., Dickinson, R. E., Bonan, G. B., Levis, S., Dai, A., and Qian, T.: Improvements to the Community Land Model and their impact on the hydrological cycle, J. Geophys. Res., 113, G01021, doi:10.1029/2007JG000563, 2008.

Oppo, D. W., McManus, J. F., and Cullen, J. L.: Abrupt climate events 500,000 to 340,000 years ago: Evidence from subpolar North Atlantic sediments, Science, 279, 1335-1338, 1998.

Oppo, D. W., Linsley, B. K., Rosenthal, Y., Dannenmann, S., and Beaufort, L.: Orbital and suborbital climate variability in the Sulu Sea, western tropical Pacific, Geochem. Geophys. Geosy., 4, 1003, doi:10.1029/2001GC000260, 2003.

Otto-Bliesner, B. L., Tomas, R., Brady, E. C., Ammann, C., Kothavala, Z., and Clauzet, G.: Climate sensitivity of moderateand low-resolution versions of CCSM3 to preindustrial forcings, J. Climate, 19, 2567-2583, 2006. 
Paillard, D., Labeyrie, L., and Yiou, P.: Macintosh program performs time-series analysis, EOS, Transactions, American Geophysical Union, 77, p. 379, 1996.

Parrenin, F., Barnola, J.-M., Beer, J., Blunier, T., Castellano, E., Chappellaz, J., Dreyfus, G., Fischer, H., Fujita, S., Jouzel, J., Kawamura, K., Lemieux-Dudon, B., Loulergue, L., MassonDelmotte, V., Narcisi, B., Petit, J.-R., Raisbeck, G., Raynaud, D., Ruth, U., Schwander, J., Severi, M., Spahni, R., Steffensen, J. P., Svensson, A., Udisti, R., Waelbroeck, C., and Wolff, E.: The EDC3 chronology for the EPICA Dome C ice core, Clim. Past, 3, 485-497, doi:10.5194/cp-3-485-2007, 2007.

Pelejero, C., Calvo, E., Barrows, T. T., Logan, G. A., and De Deckker, P.: South Tasman Sea alkenone palaeothermometry over the last four glacial/interglacial cycles, Mar. Geol., 230, 73-86, 2006.

Petit, J. R., Jouzel, J., Raynaud, D., Barkov, N. I., Barnola, J.-M., Basile, I., Bender, M., Chappellaz, J., Davis, M., Delaygue, G., Delmotte, M., Kotlyakov, V. M., Legrand, M., Lipenkov, V. Y., Lorius, C., Pepin, L., Ritz, C., Saltzman, E., and Stievenard, M.: Climate and atmospheric history of the past 420,000 years from the Vostok ice core, Antarctica, Nature, 399, 429-435, 1999.

Pflaumann, U.: Sea-surface temperatures during the last 750,000 years in the eastern equatorial Atlantic: Planktonic foraminiferal record of Meteor - cores 13519, 13521, and 16415, in: Meteor Forschungsergebnisse, Deutsche Forschungsgemeinschaft, Reihe C Geologie und Geophysik, Gebrüder Bornträger, Berlin, Stuttgart, 137-161, 1986.

Pflaumann, U., Duprat, J., Pujol, C., and Labeyrie, L.: SIMMAX: A modern analog technique to deduce Atlantic sea surface temperatures from planktonic foraminifera in deep-sea sediments, Paleoceanography, 11, 15-35, 1996.

Pisias, N. G. and Mix, A. C.: Spatial and temporal oceanographic variability of the eastern equatorial Pacific during the late Pleistocene: evidende from Radiolaria microfossils, Paleoceanography, 12, 381-393, 1997.

Pisias, N. G. and Rea, D. K.: Late Pleistocene paleoclimatology of the central equatorial Pacific: Sea surface response to the southeast trade winds, Paleoceanography, 3, 21-37, 1988.

Pisias, N. G., Mix, A. C., and Zahn, R.: Nonlinear response in the global climate system: evidence from benthic oxygen isotopic record in core RC13-110, Paleoceanography, 5, 147-160, 1990.

Pol, K., Debret, M., Masson-Delmotte, V., Capron, E., Cattani, O., Dreyfus, G., Falourd, S., Johnsen, S., Jouzel, J., Landais, A., Minster, B., and Stenni, B.: Links between MIS 11 millennial to sub-millennial climate variability and long term trends as revealed by new high resolution EPICA Dome $\mathrm{C}$ deuterium data - A comparison with the Holocene, Clim. Past, 7, 437-450, doi:10.5194/cp-7-437-2011, 2011.

Prell, W. L.: The stability of low-latitude sea-surface temperatures: An evaluation of the CLIMAP reconstruction with emphasis on the positive SST anomalies, Department of Energy, Washington D.C., 1985.

Prokopenko, A. A., Bezrukova, E. V., Khursevich, G. K., Solotchina, E. P., Kuzmin, M. I., and Tarasov, P. E.: Climate in continental interior Asia during the longest interglacial of the past 500000 years: the new MIS 11 records from Lake Baikal, SE Siberia, Clim. Past, 6, 31-48, doi:10.5194/cp-6-312010, 2010
Raymo, M. E. and Mitrovica, J. X.: Collapse of polar ice sheets during the stage 11 interglacial, Nature, 483, 453-456, 2012.

Raymo, M. E., Ganley, K., Carter, S., Oppo, D. W., and McManus, J.: Millennial-scale climate instability during the early Pleistocene epoch, Nature, 392, 699-702, 1998.

Raymo, M. E., Oppo, D. W., Flower, B. P., Hodell, D. A., McManus, F. J., Venz, K. A., Kleiven, H. F., and McIntyre, K.: Stability of North Atlantic water masses in face of pronounced climate variability during the Pleistocene, Paleoceanography, 19, PA2008, doi:10.1029/2003PA000921, 2004.

Rincón-Martínez, D., Lamy, F., Contreras, S., Leduc, G., Bard, E., Saukel, C., Blanz, T., Mackensen, A., and Tiedemann, R.: More humid interglacials in Ecuador during the past $500 \mathrm{kyr}$ linked to latitudinal shifts of the equatorial front and the Intertropical Convergence Zone in the eastern tropical Pacific, Paleoceanography, 25, PA2210, doi:10.1029/2009PA001868, 2010.

Rodrigues, T., Voelker, A. H. L., Grimalt, J. O., Abrantes, F., and Naughton, F.: Iberian Margin sea surface temperature during MIS 15 to 9 (580-300 ka): Glacial suborbital variability versus interglacial stability, Paleoceanography, 26, PA1204, doi:10.1029/2010PA001927, 2011

Rohling, E. J., Grant, K., Bolshaw, M., Roberts, A. P., Siddall, M., Hemleben, C., and Kucera, M.: Antarctic temperature and global sea level closely coupled over the past five glacial cycles, Nat. Geosci., 2, 500-504, doi:10.1038/ngeo557, 2009.

Rohling, E. J., Braun, K., Grant, K., Kucera, M., Roberts, A. P., Siddall, M., and Trommer, G.: Comparison between Holocene and Marine Isotope Stage-11 sea-level histories, Earth Planet. Sc. Lett., 291, 97-105, 2010.

Ruddiman, W. F., Shackleton, N. J., and McIntyre, A.: North Atlantic sea-surface temperatures for the last 1.1 million years, in: North Atlantic Palaeoceanography, edited by: Summerhayer, C. P. and Shackleton, N. J., Geological Society Special Publication, 155-173, 1986.

Ruddiman,W. F., Raymo, M. E., Martinson, G. D., Clement, B. M., and Backman, J.: Pleistocene evolution: Northern Hemisphere ice sheets and North Atlantic Ocean, Paleoceanography, 4, 353412, 1989.

Russon, T., Elliot, M., Sadekov, A., Cabioch, G., Corrège, T., and De Deckker, P.: Interhemispheric asymmetry in the early Pleistocene Pacific warm pool, Geophys. Res. Lett., 37, L11601, doi:10.1029/2010GL043191, 2010.

Sarnthein, M., Erlenkeuser, H., von Grafenstein, R., and Schröder C.: Stable isotope stratigraphy for the last 750.000 years, Meteor core 13519 from the eastern equatorial Atlantic., Meteor Forschungsergebnisse, Deutsche Forschungsgemeinschaft, Reihe C Geologie und Geophysik, Gebrüder Bornträger, Berlin, Stuttgart, 1984.

Schaefer, G., Rodger, J. S., Hayward, B. W., Kennett, J. P., Sabaa, A. T., and Scott, G. H.: Planktic foraminiferal and sea surface temperature record during the last $1 \mathrm{Myr}$ across the Subtropical Front, Southwest Pacific, Mar. Micropaleontol., 54, 191-212, 2005.

Schilt, A., Baumgartner, M., Blunier, T., Schwander, J., Spahni, R., Fischer, H., and Stocker, T. F.: Glacial-interglacial and millennial-scale variations in the atmospheric nitrous oxide concentration during the last 800,000 years, Quaternary Sci. Rev., 182-192, 2010. 
Schmidt, M. W., Vautravers, M. J., and Spero, H. J.: Western Caribbean sea surface temperatures during the late Quaternary, Geochem. Geophy. Geosys., 7, Q02P10, doi:10.1029/2005GC000957, 2006.

Sepulcre, S., Tachikawa, K., Vidal, L., Thouveny, N., and Bard, E.: Preservation state of metastable magnesian calcite in periplatform sediments from the Caribbean Sea over the last million years, Geochem. Geophy. Geosys., 10, Q11013, doi:10.1029/2009GC002779, 2009.

Sepulcre, S., Vidal, L., Tachikawa, K., Rostek, F., and Bard, E.: Sea-surface salinity variations in the northern Caribbean Sea across the Mid-Pleistocene Transition, Clim. Past, 7, 75-90, doi:10.5194/cp-7-75-2011, 2011.

Shackleton, N. J. and Hall, M. A.: Oxygen and carbon isotope stratigraphy of Deep Sea Drilling Project Hole 552A: PlioPleistocene glacial history, Initial Rep., Deep Sea Res., 81, 599609, 1984.

Shiau, L.-J., Yu, P.-S.,Wei, K.-Y., Yamamoto, M., Lee, T.-Q., Yu, E.F., Fang, T.-H., and Chen, M.-T.: Sea surface temperature, productivity, and terrestrial flux variations of the southeastern South China Sea over the past 800,000 years (IMAGESMD972142), Terr. Atmos. Ocean. Sci., 19, 363-376, 2008.

Siegenthaler, U., Stocker, T. F., Monnin, E., Lüthi, D., Schwander, J., Stauffer, B., Raynaud, D., Bamola, J.-M., Fischer, H., MassonDelmotte, V., and Jouzel, J.: Stable carbon cycle - climate relationship during the Late Pleistocene, Science, 310, 1313-1317, 2005.

Stein, R., Hefter, J., Grützner, J., Voelker, A., and Naafs, B. D. A.: Variability of surface water characteristics and Heinrichlike events in the Pleistocene midlatitude North Atlantic Ocean: Biomarker and XRD records from IODP Site U1313 (MIS 169), Paleoceanography, 24, PA2203, doi:10.1029/2008PA001639, 2009.

Spooner, M. I., De Deckker, P., Barrows, T. T., and Fifield, L. K.: The behaviour of the Leeuwin Current offshore NW Australia during the last five glacial-interglacial cycles, Global Planet. Change, 75, 119-132, 2011.

Sundqvist, H. S., Zhang, Q., Moberg, A., Holmgren, K., Körnich, H., Nilsson, J., and Brattström, G.: Climate change between the mid and late Holocene in northern high latitudes - Part 1: Survey of temperature and precipitation proxy data, Clim. Past, 6, 591608, doi:10.5194/cp-6-591-2010, 2010.

Tian, J., Wang, P., Cheng, X., and Li, Q.: Astronomically tuned Plio-Pleistocene benthic $\mathrm{d}^{18} \mathrm{O}$ record from South China Sea and Atlantic-Pacific comparison, Earth Planet. Sc. Lett., 203, 10151029, 2002.

Tzedakis, P. C., Raynaud, D., McManus, J. F., Berger, A., Brovkin, V., and Kiefer, T.: Interglacial diversity, Nat. Geosci., 2, 751-755, 2009.

Tzedakis, P. C.: The MIS 11 - MIS 1 analogy, southern European vegetation, atmospheric methane and the "early anthropogenic hypothesis", Clim. Past, 6, 131-144, doi:10.5194/cp-6131-2010, 2010.
Vázquez Riveiros, N., Waelbroeck, C., Skinner, L., Roche, D. M., Duplessy, J.-C., and Michel, E.: Response of South Atlantic deep waters to deglacial warming during Terminations V and I, Earth Planet. Sc. Lett., 298, 323-333, 2010.

Vázquez Riveiros, N., Waelbroeck, C., Skinner, L., Duplessy, J.-C., McManus, J., Kandiano, E. S., and Bauch, H. A.: The "MIS11 paradox" and ocean circulation: role of millenial scale events, Earth Planet. Sc. Lett., 371-372, 258-268, doi:10.1016/j.eps1.2013.03.036, 2013.

Venz, K. A., Hodell, D. A., Stanton, C., and Warnke, D. A.: A 1.0 Myr record of glacial North Atlantic intermediate water variability from ODP Site 982 in the northeast Atlantic, Paleoceanography, 14, 42-52, 1999.

Voelker, A. and De Abreu, L.: A review of abrupt climate change events in the Northeastern Atlantic Ocean (Iberian Margin): latitudinal, longitudinal and vertical gradients, in: Understanding the Causes, mechanisms and extent of the Abrupt Climate Change, edited by: Rashid, H., Polyak, L., and Mosley-Thompson, E., AGU Geophysical Monograph, Washington DC, 15-38, 2011.

Voelker, A., Martin, P., Lebreiro, S., and Abrantes, F.: Millennial scale deep/intermediate water changes at the mid-depth Portuguese margin during Marine Isotope Stage (MIS) 11, Quaternary Int., 436, 167-168, 2007.

Voelker, A. H. L., Rodrigues, T., Billups, K., Oppo, D., McManus, J., Stein, R., Hefter, J., and Grimalt, J. O.: Variations in midlatitude North Atlantic surface water properties during the midBrunhes (MIS 9-14) and their implications for the thermohaline circulation, Clim. Past, 6, 531-552, doi:10.5194/cp-6-531-2010, 2010.

von Grafenstein, R., Zahn, R., Tiedemann, R., and Murat, A.: Planktonic $\mathrm{d}^{18} \mathrm{O}$ records at Sites 976 and 977, Alboran Sea: Stratigraphy, forcing, and paleoceanographic implications, Proc. ODP, Sci. Results, 161, 469-479, 1999.

Waelbroeck, C., Labeyrie, L., Duplessy, J.-C., Guiot, J., Labracherie, M., Leclaire, H., and Duprat, J.: Improving past sea surface temperature estimates based on planktonic fossil faunas, Paleoceanography, 13, 272-283, 1998.

Weller, P.: Variability of paleoproductivity, paleotemperature and terrestrial organic matter supply in the mid-Pleistocene southern south Atlantic: Implications from biomarker records (ODP-LEG 177), Ph.D., Alfred-Wegener-Institut für Polar- und Meeresforschung, Universität Bremen, Bremerhaven, 169 pp., 2006.

Yeager, S. G., Shields, C. A., Large, W. G., and Hack, J. J.: The low-resolution CCSM3, J. Climate, 19, 2545-2566, 2006.

Zhang, Q., Sundqvist, H. S., Moberg, A., Körnich, H., Nilsson, J., and Holmgren, K.: Climate change between the mid and late Holocene in northern high latitudes - Part 2: Model-data comparisons, Clim. Past, 6, 609-626, doi:10.5194/cp-6-609-2010, 2010. 